\title{
THE ARBITRABILITY OF INVESTOR-STATE TAXATION DISPUTES IN INTERNATIONAL COMMERCIAL ARBITRATION
}

\author{
LAWS 521: International Arbitration
}

Submitted for the LLB (Honours) Degree

\author{
Faculty of Law
}

Victoria University of Wellington

2013 


\section{Table of Contents}

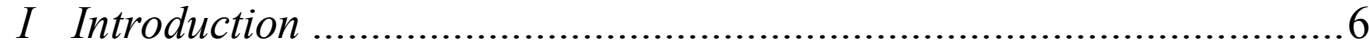

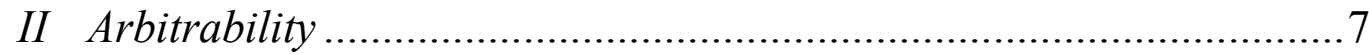

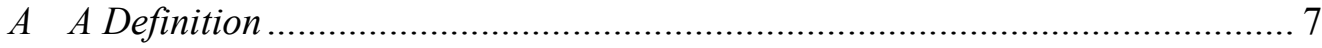

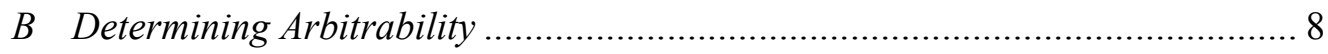

1 Law governing the arbitration agreement ............................................. 9

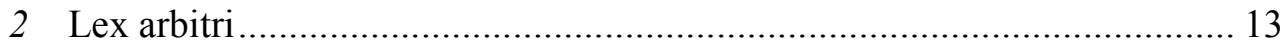

3 International public policy ................................................................... 15

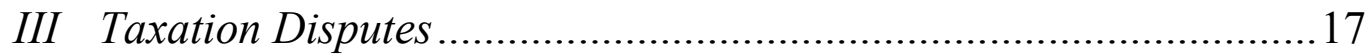

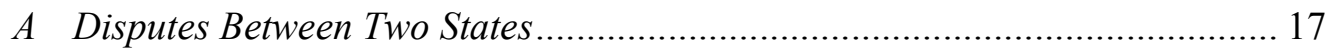

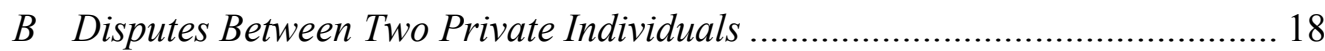

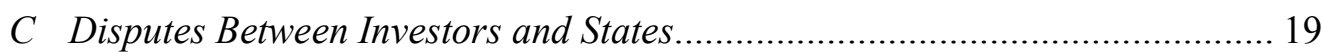

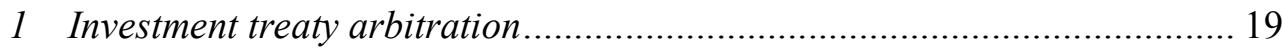

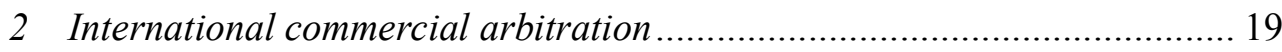

(a) Foreign party will abide by the tax law of the host-state ....................... 20

(b) Limited tax exemption or reduction for foreign party ............................ 21

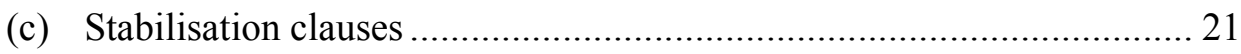

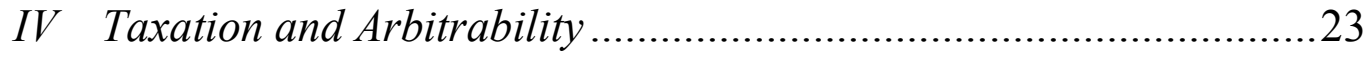

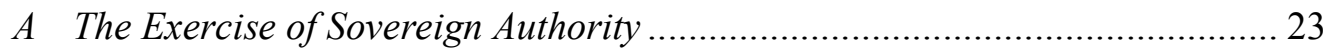

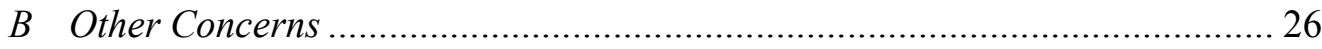

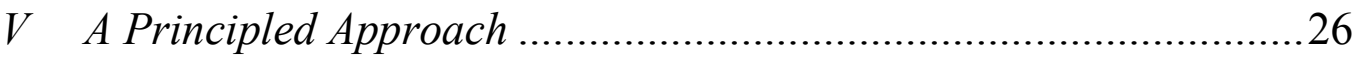

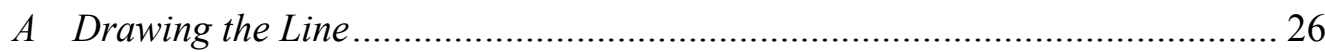

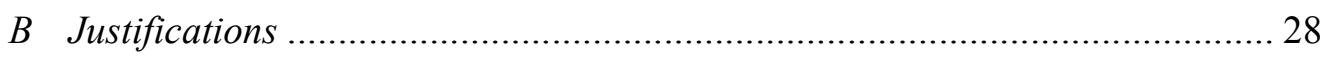

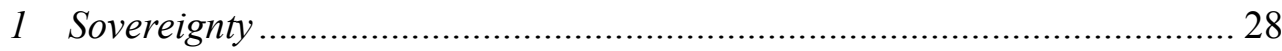

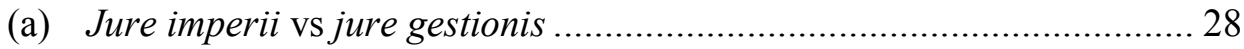

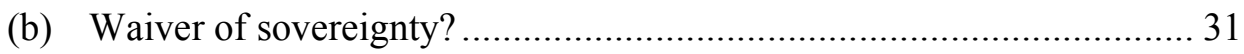

(c) Rule against foreign enforcement of revenue laws............................... 32

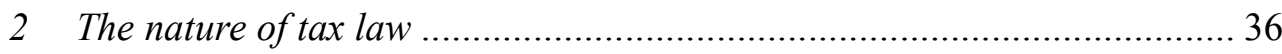

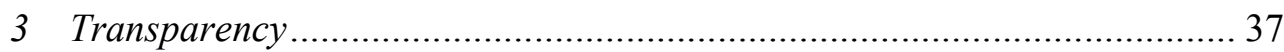

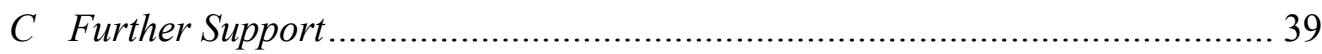

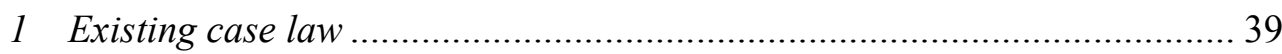

(a) Cases demonstrating contractual disputes are clearly arbitrable ............. 40

(b) Cases demonstrating disputes implicating sovereignty are not arbitrable 41

(c) Comparison with cases that arise in a vertical context .......................... 44

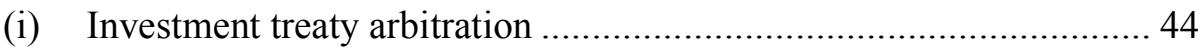

(ii) Iran-US Claims Tribunal jurisprudence............................................ 46

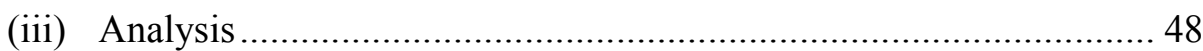

2 Move towards greater arbitrability ........................................................... 49 


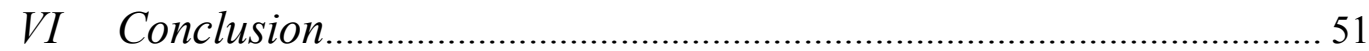

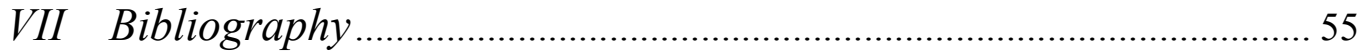

The text of this article comprises approximately 14,931 words, excluding abstract, footnotes and bibliography. 


\begin{abstract}
Despite the expanding scope of arbitrability in recent times, the arbitrability of tax disputes remains an unsettled issue. While it has been a hotly discussed topic in the field of international investment arbitration, it also warrants attention in the context of international commercial arbitration. In particular, the arbitrability of investor-state taxation disputes in this area raises a number of challenging issues. Accordingly, this article provides an in depth examination of the arbitrability of investor-state taxation disputes in international commercial arbitration. It concludes that traditional concerns regarding the arbitrability of tax disputes do not, in principle, support the inarbitrability of all tax disputes. Rather, there is a logical distinction to be drawn between taxation disputes that directly implicate the sovereignty of states, and disputes as to taxation that are merely contractual in nature, and only involve taxation indirectly. In reaching this conclusion, this article also yields some insights into both the question of which law should govern arbitrability and also into the nature of arbitrability more generally, in the light of the developments that have occurred in this area.
\end{abstract}




\section{Introduction}

It is now reasonably clear as far as the literature is concerned that investor-state tax disputes may be arbitrable in the context of investment treaty arbitration. Much academic discussion has focussed on this issue. ${ }^{1}$ However, the position remains murky in the field of international commercial arbitration. This is a context in which there has not been much discussion of the arbitrability of tax disputes, despite it being one in which the issue commonly arises. This article therefore sets out to offer a comprehensive analysis of the arbitrability of investor-state taxation disputes in the field of international commercial arbitration. This involves examining disputes where states and investors operate on the same plane, as contracting parties. Particularly due to this horizontal playing field, challenging questions arise, primarily concerning state sovereignty.

A principled resolution will be offered to this problem. This article will argue that there is a logical distinction to be drawn between taxation disputes that directly implicate the sovereignty of states, and disputes as to taxation that are merely contractual in nature, and only involve taxation indirectly. In doing so, it will begin by examining arbitrability and the issues associated with what law should govern the question of arbitrability. However, this article will not offer any final pronouncements on which law should govern. Rather, it will proceed to contextualise the situations in which tax disputes arise, with a particular focus on the kinds of contractual clauses in investor-state contracts, and examine the traditional objections to the arbitrability of such disputes. It will then consider the extent to which the traditional objections to the arbitrability of tax disputes succeed, the existing case law, and general trends towards arbitrability. It will conclude that the distinction suggested can be generally supported and that only those disputes involving taxation indirectly should be arbitrable. In doing so it will discern some broader insights into arbitrability.

1 See for example William W Park "Arbitrability and Tax" in Loukas A Mistelis and Stavros L Brekoulakis (eds) Arbitrability: International and Comparative Perspectives (Kluwer Law International, The Netherlands, 2009); William Park Arbitration of International Business Disputes: Studies in Law and Practice (Oxford University Press, Oxford, 2006); Thomas Walde and Abba Kolo "Investor-State Disputes: The Interface Between Treaty-Based International Investment Protection and Fiscal Sovereignty" (2007) 35 Intertax 424; and Natalia Quinones Cruz in her article "International Tax Arbitration and the Sovereignty Objection: The South American Perspective" (2008) 51 Tax Notes International 533. 


\section{Arbitrability}

\section{A A Definition}

The question of arbitrability places limits on the legal issues that may be adjudicated by an arbitral tribunal. ${ }^{2}$ According to Redfern and Hunter "[a]rbitrability ... involves determining which types of dispute may be resolved by arbitration and which belong exclusively to the domain of the courts". ${ }^{3}$ In other words arbitrability draws the line between freedom of contract and the role of the courts as protectors of the public interest. ${ }^{4}$ Thus, traditionally arbitrability is concerned with particular subject-matters that cannot be decided by arbitration, "even if the parties have otherwise validly agreed to arbitrate such matters". ${ }^{5}$ This doctrine developed on the basis that: ${ }^{6}$

some matters so pervasively involve public rights, or interests of third parties, which are the subjects of uniquely governmental authority, that agreements to resolve such disputes by 'private' arbitration should not be given effect.

Determining which subject-matters are incapable of being arbitrated on this basis is the "classic function of arbitrability". ${ }^{7}$ This function is known as objective arbitrability, substantive arbitrability, arbitrability rationae materiae or more generally as the nonarbitrability doctrine. ${ }^{8}$ It is important to distinguish this notion of arbitrability from subjective, or contractual, arbitrability. ${ }^{9}$ Subjective arbitrability is concerned with whether there is a valid agreement to arbitrate, according to the principles of contract law. ${ }^{10}$ Unlike subjective arbitrability, objective arbitrability raises questions of "fundamental policy". ${ }^{11}$ These questions also influence the validity of the arbitration

2 Nigel Blackaby and others Redfern and Hunter on International Arbitration (Oxford University Press, Oxford, 2009) at 123.

3 Blackaby, above $\mathrm{n} 2$, at 123 .

4 Thomas E Carbonneau with Francois Janson "Cartesian Logic and Frontier Politics: French and American Concepts of Arbitrability" (1994) 2 Tul J Intl \& Comp L 193 at 194.

5 Gary B Born International Commercial Arbitration (Kluwer Law International, Austin, 2009) at 767. See also Carbonneau and Janson, above n 4, at 195 and 210; and Janet Walker "Arbitrability: Are there Limits" (paper presented at the LCIA Symposium, Montreal, October 2004), at 2.

6 Born, above n 5, at 768; Blackaby, above n 2, at 123; and David AR Williams and others Williams \& Kawharu on arbitration (Lexis Nexis, Wellington, 2011) at [7.3.1].

7 Carbonneau and Janson, above $\mathrm{n} 4$, at 195.

8 Carbonneau and Janson, above n 4, at 195, 196 and 210. See also Born, above n 5, at 767 and Emmanuel Gaillard and John Savage (eds) Fouchard, Gaillard, Goldman on International Commercial Arbitration (Kluwer Law International, The Hague, 1999) at 313.

9 Carbonneau and Janson, above $\mathrm{n}$ 4, at 195, 196 and 210. This is also known as "arbitrability rationae personae". See also Gaillard and Savage, above n 8, at 313.

10 Carbonneau and Janson, above n 4, at 195, 196 and 210.

11 Carbonneau and Janson, above $\mathrm{n}$ 4, at 195. 
agreement, but in a broader sense than subjective arbitrability. Consequently, objective arbitrability is a condition placed on the validity of both the agreement to arbitrate, and the arbitrator's jurisdiction.

\section{$B \quad$ Determining Arbitrability}

The question of arbitrability is not easily determined in the abstract. One must first determine the law governing arbitrability, thereby implicating an array of choice of law issues. At the most basic level this issue arises because the question of arbitrability "is governed by national law" and in the international context "there may be more than one national law that connects with the arbitration". ${ }^{12}$ Further, these national laws, while raising a "common set of concerns", "differ from nation to nation". ${ }^{13}$ Thus, the answer to whether a dispute is arbitrable may change depending on which law applies to determine arbitrability. ${ }^{14}$

However, the question of the law governing arbitrability is more complicated than this basic description suggests. This is because a determination of arbitrability is not only relevant at the beginning of the arbitral proceedings. In fact, there are several stages in the process, and also several different fora, where it may be invoked. ${ }^{15}$ These include (a) before the tribunal at the beginning of the proceedings; (b) before state courts, either as a matter to be determined before the arbitration can go ahead, or as a question of whether the award should be set aside; and (c) before the court of enforcement. ${ }^{16}$ As a result there are many options when considering the law that may apply to determining questions of arbitrability. Gary Born lists these as: $:^{17}$

(a) the law of the nation in which enforcement of an award is being or will eventually be sought; (b) the law governing the parties' arbitration agreement; (c) the law of the seat of the arbitration; (d) the law of the judicial forum where an arbitration agreement is sought to be enforced; (e) the law that provides the basis for the relevant substantive claim that is said to be non-arbitrable; or (f) a uniform international definition of non-arbitrability derived from the New York Convention (or other relevant conventions).

12 Okezie Chukwumerije Choice of Law in International Commercial Arbitration (Quorum Books, London, 1994) at 53.

13 Born, above n 5, at 767-768 and 775. See also Blackaby, above n 2, at [2.27].

14 See for example, Blackaby, above n 2, at [3.44].

15 Born, above n 5, at 516.

16 Bernard Hanotiau "What Law Governs the Issue of Arbitrability?" (1996) 12 Arb Intl 391 at 391. See also Born, above n 5, at 516.

17 Born, above n 5, at 517. 
Thus, as Bernard Hanotiau notes, the choice regarding which law governs arbitrability is challenging and "may depend upon the stage at which [arbitrability] is raised". ${ }^{18}$ Putting aside the issue of enforcement, where it is clear that the law governing arbitrability is the law of the forum where enforcement is sought, ${ }^{19}$ there is no consensus about how the choice as to which law governs should be made. ${ }^{20}$ In saying this, a review of the literature makes it clear that there are two prime contenders for the law governing arbitrability, at least when it is being decided by an arbitral tribunal. These are the law governing the arbitration agreement and the lex arbitri. ${ }^{21}$ It is appropriate to examine the merits of each approach, with specific focus on investor-state tax disputes.

\section{Law governing the arbitration agreement}

The law governing the arbitration agreement is the "law expressly or impliedly chosen by the parties" or "in the absence of such choice, the law which is most closely connected with the arbitration agreement, which will in general be the law of the seat of the arbitration". ${ }^{22}$ Dicey, Morris and Collins on the Conflict of Laws suggests that in most cases the parties' express or implied choice can be discerned. ${ }^{23}$ In discerning such a

18 Hanotiau, above n 16, at 393.

19 The United Nations New York Convention on the Recognition and Enforcement of Foreign Arbitral Awards 330 UNTS 3 (opened for signature 10 June 1958, entered into force 7 June 1959), art V(2)(b). See also Albert Jan van den Berg The New York Arbitration Convention of 1958: Towards a Uniform Judicial Interpretation (Kluwer Law and Taxation Publishers, Netherlands, 1981) at 369; Born, above n 5, at 517; Stavros L Brekoulakis "Law Applicable to Arbitrability: Revisiting the Revisited Lex Fori" in L Mistelis and S Brekoulakis (eds) Arbitrability: International and Comparative Perspectives (Kluwer Law International, The Netherlands, 2009) at [6-3]; and JeanFrancois Poudret and Sebastien Besson Comparative Law of International Arbitration (2nd ed, Sweet \& Maxwell, London, 2007) at [331].

20 Born, above n 5, at 516 and 517. For suggestions as to how to approach this issue see Antoine Kirry "Arbitrability: Current Trends in Europe" (1996) 12 Arb Intl 373; Hanotiau, above n 16; Brekoulakis, above n 19, at ch 6; and Blackaby, above n 2, at [2.115] and [10.42].

21 Poudret and Besson, above n 19, at [332]. See also Born, above n 5, at 521-530 (referring to the rules of the seat, the law governing the agreement, and an international approach); W Laurence Craig, William W Park, and Jan Paulsson International Chamber of Commerce Arbitration (3rd ed, Oceana Publications, Dobbs Ferry NY, 2000) at 61 (referring to the law that governs the agreement); Hanotiau, above n 16, at 392 (referring to the law governing the arbitration agreement and the law of the seat of the arbitration); and Loukas A Mistelis "Arbitrability - International and Comparative Perspectives: Is Arbitrability a National or an International Law Issue" in Loukas A Mistelis and Stavros L Brekoulakis (eds) Arbitrability: International and Comparative Perspectives (Kluwer Law International, The Netherlands, 2009) at [1.34] and [1.35] (referring to the lex arbitri and international public policy).

22 Lawrence Collins and others (eds) Dicey, Morris and Collins on the Conflict of Laws (15ed, Sweet and Maxwell, London, 2012) at 829, [16-016] and [16-019] [Dicey]. See also Sulamerica v Enesa Engenharia [2012] EWCA Civ 638.

23 Dicey, above n 22, at [16-016]. 
choice, "in many cases, the law applicable to the main contract will" be influential. ${ }^{24}$ This is particularly important in the context of investor-state contracts, where the law governing the main contract is often the law of the host-state. ${ }^{25}$ For the purposes of analysing the merits of using the law governing the arbitration agreement to determine arbitrability, it will be assumed that the law governing the agreement will be the law of the host-state.

The general argument here is that it should be a function of the law governing the agreement to determine the outer bounds of what the parties can or cannot agree to arbitrate. The theory offered by the literature for this approach to determining arbitrability lies in the autonomy of the parties. ${ }^{26}$ The idea here is that the choice of the parties as to what law applies to their agreement to arbitrate should be respected in determining arbitrability. ${ }^{27}$ It is also said that this view accords with the need for contractual security. ${ }^{28}$

This approach may be viewed as meritorious insofar as it seeks to apply a law that is more likely to be causally connected to the dispute. Okezie Chukwumerije, advocating for governing law to be determined on the basis of "the jurisdiction whose policy interests are most directly implicated by the parties' transaction", ${ }^{29}$ notes that the "law applicable to the arbitration agreement would be a relevant standard in determining arbitrability in cases where it is the law of the country that is most closely connected to the underlying transaction". ${ }^{30}$ Given the law governing the arbitration agreement is likely to be the law of the host-state, this criterion would be met. Prima facie, this appears to be a strong reason for determining arbitrability on the basis of the law governing the arbitration agreement, at least in the context of investor-state contractual disputes. However, several fundamental issues arise.

24 However this will not always be the case: Dicey, above n 22, at [16-012].

25 See for example Mineral Development Agreement between the Government of the Republic of Liberia, China-Union (Hong Kong) Mining Co Ltd and China-Union Investment (Liberia) Bong Mines Co Ltd (19 January 2009) sourced from Liberia Extractive Industries Transparency Initiative (LEITI) <http:/www.leiti.org.lr/>, s 29 (providing for the applicability of Liberian law); and the Concession Agreement for Gola Forest East and Gola Forest West, Forest Reserves (Ratification) Act 1977 in Peter Fischer (ed) A Collection of International Concessions and Related Instruments: Contemporary Series (Volume 1, Oceanea Publications, United States of America, 1981), art 9.2.2 (In this agreement the arbitration clause itself specified the law governing the agreement to be the law of Sierra Leone, the host-state.)

26 Poudret and Besson, above n 19, at [332].

27 Poudret and Besson, above n 19, at [332]; and Chukwumerije, above n 12, at 54.

28 Chukwumerije, above n 12, at 54. This position is endorsed by Hanotiau, above n 16, at 393-395.

29 Chukwumerije, above n 12, at 55.

30 Chukwumerije, above n 12, at 54. 
A general issue may arise where the law of the seat concerning the arbitrability of the dispute is different from the law governing the agreement. ${ }^{31}$ Difficulties arising in this regard have been put forward as a reason for using the lex arbitri over the law governing the arbitration agreement. ${ }^{32}$ For example, the jurisdiction where the arbitral tribunal is seated may consider the issue inarbitrable, contrary to the law governing the agreement. This leads one to question whether the tribunal can ignore the law of the seat, in the light of its duty to the parties to "render an enforceable award". ${ }^{33}$ Such an outcome does not seem desirable given arbitrability is essentially an "escape device" for a state such as the seat, and the tribunal draws on the laws of the seat for support in conducting the arbitration. ${ }^{34}$

Conversely, the law of the seat may consider an issue is arbitrable, where the law governing the agreement considers otherwise. ${ }^{35}$ Mihail Danov notes that in this scenario the arbitration should go ahead in the seat. However: ${ }^{36}$

the arbitration agreement would become unenforceable in any country where the arbitrability had been determined by the law governing the arbitration agreement. This result would be unfortunate since concurrent ordinary court proceedings would not be stayed in those countries.

Danov concludes that the use of the law governing the arbitration agreement "would lead to an appropriate result only if it [coincided] with the law of the seat". ${ }^{37}$

Further, more fundamental issues arise in the investor-state context. The overarching issue is that choosing the law governing the arbitration agreement essentially reduces the question of arbitrability to one of the consent of the parties. This is as a result of the law governing the agreement most likely being the law of the hoststate. It is suggested that this appears to take the autonomy justification for using the law governing the arbitration agreement to an extreme. It is one thing to respect parties' choices as to the applicable law, and quite another for that choice to be allowed to undermine the basis of the doctrine of arbitrability.

For example, imagine a state had agreed to make tax issues arbitrable in an investment contract, but the law of that state, which governed the arbitration agreement,

31 Blackaby, above n 2, at [3.43].

32 Mihail Danov "The law governing arbitrability under the Arbitration Act 1996" [2008] LMCLQ 536 at 539 .

33 Chukwumerije, above n 12, at 55.

34 Born, above n 5, at 525; and Dicey, above n 22, at [16-029].

35 Danov, above n 32, at 539 .

36 Danov, above n 32, at 539.

37 Danov, above n 32, at 539. 
stated that tax issues were inarbitrable. ${ }^{38}$ In this context, the use of the law governing the agreement to determine arbitrability is not workable. The state will likely be precluded from relying on its own law to avoid the arbitrability of the dispute, thereby reducing the issue to one of consent. ${ }^{39}$ In other words, if the parties consent to arbitrating the dispute, it will be arbitrable. This conflates the questions of arbitrability and jurisdiction and as such, is not very analytically satisfying. A decision as to whether something is arbitrable should not hinge on the parties consent, given the whole point of the doctrine is to consider whether some matters are not suitable for resolution by arbitration, despite the parties having agreed to arbitrate them.

A similar argument is advanced more generally by Poudret and Besson. In their view the reasons put forward concerning party autonomy for the use of the law governing the arbitration agreement to determine arbitrability are unpersuasive. This is because: ${ }^{40}$

arbitrability constitutes a legal restriction on the autonomy of the parties. Such autonomy only exists within the limits of the mandatory rules of the law of the seat governing the arbitration, which the arbitral tribunal must respect. Therefore, the parties cannot deviate from the criteria of arbitrability established by such law, even if they submit their arbitration agreement to the law of another country. Otherwise, it would be too easy to evade the mandatory character of the restrictions to the arbitrability of certain disputes.

These considerations demonstrate that the law governing the arbitration agreement is an unusual starting point for determining arbitrability in the investor-state context, despite probably being most closely connected with the dispute, in the sense that one of the parties has complete control over the law. Perhaps it could be acceptable if arbitrability were only concerned with the public interest of the state involved in the transaction. However, where tax disputes are involved, wider public policy considerations involving the international system of states come into play. ${ }^{41}$

38 For example, Cruz, above n 1, notes that many South American countries run into problems when agreeing to arbitrate tax disputes, because this is prohibited by their constitutions or domestic law.

39 This would likely be an application or variation of the "rule that states ... cannot rely on restrictive provisions of their own law to challenge the validity of arbitration agreement into which they unreservedly entered". Gaillard and Savage, above n 8, note (at [547]) that this rule is "now firmly established".

40 Poudret and Besson, above n 19, at [332]. (Emphasis added).

41 See section $\mathrm{V}(\mathrm{B})(1)(\mathrm{c})$ below at 31. 


\section{Lex arbitri}

The lex arbitri is the law of the seat of the arbitration. ${ }^{42}$ It is the "procedural law of an arbitration", ${ }^{43}$ dealing with both the "internal procedure of the arbitration itself", for example "commencement of the arbitration, appointment of arbitrators, pleadings, provisional measures, evidence, hearings and awards" and the "external intervention of national courts in the arbitral process". ${ }^{4}$

The general argument here is that "since the arbitration is to proceed in the arbitral seat, the law of that jurisdiction", being responsible for governing procedural matters, "should determine the threshold question whether the dispute is subject to arbitration". ${ }^{45}$ In this vein, it has been suggested that arbitrability is a procedural issue "to do with the compulsory jurisdiction of courts (or of other public authorities)". ${ }^{46}$ As arbitrability is a preliminary matter to be decided before the hearing of the substantive dispute, it seems natural that the law that governs the procedure of the arbitration should also apply to the question of arbitrability. In this respect it is worth distinguishing arbitrability from issues pertaining to the arbitration agreement clearly governed by the law governing the arbitration agreement, such as "the interpretation, effect and scope". ${ }^{47}$ Arbitrability is a separate legal question, only relating to the arbitration agreement indirectly in the sense that, once arbitrability is determined, it may impact the arrangement between the parties. Indeed, Redfern and Hunter lists arbitrability as one of the "matters with which the lex arbitri might be expected to deal". ${ }^{48}$

The inherent problem with the view that the lex arbitri should govern the question of arbitrability is that it is unlikely to have a "close connection with the underlying commercial agreement". ${ }^{49}$ Where the parties have specified a seat, it is likely that choice was informed by factors such as convenience, or the availability of a neutral forum, as opposed to being informed by the law of the particular forum chosen..$^{50}$ Further, if the

42 Dicey, above n 22, at 829 and [16-035].

43 Dicey, above n 22, at [16-029].

44 Dicey, above n 22, at [16-029]. While the lex arbitri may be the same as the law governing the arbitration agreement where the parties' choice regarding the law of the arbitration agreement cannot be discerned, this article will assume that this is not the case.

45 Born, above $\mathrm{n}$ 5, at 521. Poudret and Besson, above n 19, at [332]-[336] support the view that the lex arbitri is the correct law to use in determining arbitrability, both for the arbitral tribunal and the courts.

46 Danov, above n 32, at 538.

47 Chukwumerije, above n 12, at 34.

48 Blackaby, above n 2, at [3.43].

49 Chukwumerije, above $\mathrm{n} 12$, at 55.

50 Chukwumerije, above n 12, at 59; Dicey, above n 22, at [16.009]; and Campbell McLachlan Lis Pendens in International Litigation (Martinus Nijhoff Publishers, Lieden/Boston, 2009) at 189-190. 
parties have not specified a seat, the seat may not be chosen by the parties themselves. ${ }^{51}$ Therefore it is not necessarily the case that the law of the seat has any "connection with the subject-matter of the dispute or the parties". ${ }^{52}$

On the contrary, it has been suggested that by "choosing a country in which to arbitrate, the parties create a close connection between the arbitration and that country".53 Mihail Danov argues that such a choice indicates the parties have "implicitly" "chosen the laws of that place to govern the arbitrability". ${ }^{54}$ Viewing arbitrability as a procedural matter, it should be "governed by the law of the country in which the arbitration is held, on the ground that it is the country most closely connected with the proceedings", ${ }^{55}$ it being "well established that, when contracting to arbitrate in a particular place, parties have consented to having procedural matters governed by the law of that place". ${ }^{56}$ On this view then, there is a sufficient connection between the law of the seat and the dispute.

Further, the context of tax disputes demonstrates that seeking to find which jurisdiction's "policy interests are most directly implicated" is not the most appropriate criterion. This criterion would suggest that the law of the host-state should govern arbitrability. However, there are broader policy considerations than just those of the host-state, which need to be considered. This will be elaborated on in depth below, ${ }^{57}$ but for now it is sufficient to say that these considerations suggest that the law of the seat could have valid reasons for denying arbitrability, despite not having any particular connection with the underlying dispute at all. Thus, it appears to be more appropriate for the lex arbitri to govern arbitrability. ${ }^{58}$

51 Chukwumerije, above n 12, at 59.

52 Dicey, above n 22, at [16.009].

53 Danov, above $\mathrm{n} 32$, at 540.

54 Danov, above $\mathrm{n} 32$, at 540.

55 James Miller v Whitworth Street Estates [1970] 1 Lloyd's Rep 269; [1970] AC 583 (HL) at 607, 609, 612 and 615. See also Danov, above n 32, at 541.

56 Danov, above $\mathrm{n} 32$, at 541.

57 See section $\mathrm{V}(\mathrm{B})(1)(\mathrm{c})$ below at 31 .

58 Chukwumerije, above $\mathrm{n} 12$, at 59 suggests there may also be forum-shopping considerations. However, forum-shopping issues may arise regardless of what law is governing the issue of arbitrability, and this article will not deal further with this consideration. 


\section{International public policy}

In addition, there is the potential to use rules of international public policy to determine arbitrability. ${ }^{59}$ The term international public policy may be used to refer to several interrelated concepts. ${ }^{60}$ This article will refer to it in the sense of transnational public policy, as opposed to national rules on international public policy. ${ }^{61}$ Transnational public policy "can be defined as the set of legal principles, not belonging to the law of a particular State".$^{62}$ It is reliant on consensus between states..$^{63}$ International public policy in this sense presents a genuine third choice to the options discussed above, at least with respect to arbitral tribunals, who are "not the organs of a particular legal order". ${ }^{64}$

The starting point for determining arbitrability under this approach would be that a dispute is arbitrable unless there is a rule of transnational public policy against it. In the context of tax disputes Emmanuel Gaillard has suggested that there is "no rule of international public policy opposing the arbitrability of tax disputes per se". ${ }^{65}$ However, this appears to pose the issue too broadly. This is because there exists the potential for significant international consequences, if the arbitrability of some kinds of disputes involving taxation is allowed. ${ }^{66}$ Again, these issues will be discussed in depth. All that need be noted now is that there may be a more nuanced approach, whereby there is a rule of transnational public policy that some kinds of taxation disputes are not arbitrable, and that such a rule find its basis in concerns relating to sovereignty and general practice indicating the consent of states to such a principle.

59 Gaillard and Savage, above n 8, at [559] and [541]; Born, above n 5, at 530; Mistelis, above n 21, at [1.35]; L Yves Fortier "Arbitrability of Disputes" in Gerald Aksen and others (eds) Global Reflections on International Law, Commerce and Dispute Resolution (ICC Publishing, Paris, 2005) at 274; Karim Yousef "The Death of Inarbitrability" in Loukas A Mistelis and Stavros L Brekoulakis (eds) Arbitrability: International and Comparative Perspectives (Kluwer Law International, The Netherlands, 2009) at [3-53]; and Craig, Park and Paulsson, above n 21, at [5-07].

60 Mark A Buchanan "Public Policy and International Commercial Arbitration" (1988) 26 Am Bus LJ 511 at 514 .

61 See International Law Association Committee on International Commercial Arbitration "Final Report on Public Policy as a Bar to Enforcement of International Arbitral Awards" (International Law Association New Delhi Conference, 2002) at [11]; and Pierre Mayer "Effect of International Public Policy in International Arbitration?" in Loukas A Mistelis and Julian DM Lew (eds) Pervasive Problems in International Arbitration (Kluwer Law International, The Netherlands, 2006) at [2-2].

62 Mayer, above n 61, at [2-8].

63 International Law Association, above n 61, at [11]; and Mayer, above n 61, at [2-9].

64 Gaillard and Savage, above n 8, at [559].

65 Emmanuel Gaillard "Tax Disputes Between States and Foreign Investors" (1997) 217 NYLJ 25.

66 See section $\mathrm{V}(\mathrm{B})(1)(\mathrm{c})$ below at 31. 
In considering transnational public policy as a contender for the law governing arbitrability it is important to recognise that this is not its most conventional use. This is because typically the function of public policy is eliminating "agreements, rules or decisions that would contravene certain fundamental values or interests". ${ }^{67}$ This may be either during the substantive determination or when enforcement is sought. ${ }^{68}$ Conversely, the use of public policy in determining arbitrability occurs $a b$ initio and does not involve disapplying other rules or decisions, per se. ${ }^{69}$

However, it has been recognised that it is appropriate to refer to public policy in the context of determining arbitrability. ${ }^{70}$ In many ways, moving to a transnational public policy approach to arbitrability seems like the natural progression from the expansion of arbitrability that has occurred on the basis of national rules on international public policy. ${ }^{71}$ The approach to international arbitration has been increasingly broadened with reference to international commerce, compared to tighter restrictions that may exist on the basis of public policy domestically. ${ }^{72}$ Because of this it may be more appropriate to take a "genuinely international" approach to determining arbitrability. ${ }^{73}$

Further, a move to focusing on transnational public policy is particularly apt given it would remove arbitrability from the domain of national law and remove associated choice of law issues. While the use of public policy in this context is not its most conventional use, it should perhaps be less controversial, in that it is being applied to a question over which, by definition, the parties should have no control. The fact that transnational public policy is not tied in with the law that the parties have selected,

67 Mayer, above n 61, at [2-12]. See also Javier Garcia de Enterria "The Role of Public Policy in International Commercial Arbitration" (1989-1990) 21 Law \& Poly Int Bus 389 at 392.

68 Garcia de Enterria, above n 67, at 393.

69 Karl-Heinz Bockstiegel "Public Policy and Arbitrability" in Pieter Sanders (ed) Comparative Arbitration Practice and Public Policy in Arbitration (ICCA Congress Series No 3, Kluwer Law and Taxation Publishers, New York, 1986) at 178.

70 Fifi Junita "Public Policy Exception in International Commercial Arbitration - Promoting Uniform Model Norms" (2012) 5 Contemp Asia Arb J 45 at 56-57; Karl-Heinz Bockstiegel "Public Policy as a Limit to Arbitration and Enforcement" (paper presented at the 11th IBA International Arbitration Day and United Nations New York Convention Day, New York, February 2008) at 5; Bockstiegel, above n 69, at 178; and Garcia de Enterria, above n 67, at 394. Further, Buchanan's explanation of the aim of public policy, above $\mathrm{n} 60$, at 513 , ties in closely with the rationale behind arbitrability.

71 Blackaby, above n 2, at [2.114]. See also Born, above n 5, at 775-776 and Craig, Park, and Paulsson, above n 21, at [7.05]; Bockstiegel, above n 69, at 181; and section V(2) below at 48.

72 Blackaby, above n 2, at [2.114]. See also Born, above n 5, at 775-776 and Craig, Park, and Paulsson, above n 21, at [7.05]; and Buchanan, above n 60, at 514 and 519.

73 Gaillard and Savage, above n 8, at [559]. 
arguably appropriately separates the question of the law governing arbitrability, and thus arbitrability itself, from issues involving the choice of, or consent of, the parties. ${ }^{74}$

In addition, public policy in this context can be viewed as performing a similar sort of overriding function to standard applications of public policy, in that the rule of transnational public policy modifies the base assumption of arbitrability. ${ }^{75}$ The use of public policy in this context therefore eliminates the arbitrability of certain disputes that would "contravene certain fundamental values or interests".

It is not the place of this article to pronounce finally upon the question of the law governing arbitrability. Having examined the issues that arise, this article will proceed to examine in principle whether tax disputes should be arbitrable, and if so, to what extent. In this sense, the article may be seen to provide a guide as to where a rule of public policy may fall, but the discussion is of broader application.

\section{Taxation Disputes}

In order to determine whether taxation disputes should be arbitrable from a principled perspective, one must first understand the context in which such disputes arise. The question of the arbitrability of taxation disputes may arise in the context of three different kinds of dispute.

\section{A Disputes Between Two States}

Disputes between two states are governed by tax treaties. ${ }^{76}$ International tax treaties primarily concern double-taxation or tax cooperation. ${ }^{77}$ Arbitration is increasingly being encouraged as a means to resolve state-state disputes under these treaties. ${ }^{78}$ The Organisation for Economic Cooperation and Development (OECD) in particular, has

74 Two points should be noted. First a lack of party consent may raise issues as to the source of the arbitrator's authority to use transnational public policy. See for example Michael Pryles "Reflections on Transnational Public Policy" (2007) 24 J Intl Arb 1 at 7. Second, the consent of the state still has a role to play more generally, given the consensus of states is required. In this regard, it is important to note that there is conceptually a difference between the consensus of states on a macro level, and the consent of a state - perhaps acting in a commercial capacity - to a particular provision on a micro level.

75 Such an assumption seems appropriate given the ever-expanding nature of arbitrability.

76 Ad Hoc Group of Experts on International Cooperation in Tax Matters "Arbitration in International Tax Matters" (29 August 2001) ST/SG/AC.8/2001/CRP.15 at 2.

77 Thomas W Waelde and George Ndi "Stabilizing International Investment Commitments: International Law Versus Contract Interpretation" (1996) 31 Tex Intl LJ 215 at 427.

78 See Waelde and George, above n 77, at 427; Cruz, above n 1, at 533; and Park "Arbitrability and Tax", above n 1, at [10-8]. 
been pushing for the use of arbitration, recently incorporating an arbitration clause in the OECD Model Tax Treaty. ${ }^{79}$ Disputes of this nature are fundamentally distinct from those that this article is concerned with, in that they deal with a situation where states, in exercise of their sovereign right, have agreed to resolve tax disputes between them in a particular way, against the background of public international law.

\section{B Disputes Between Two Private Individuals}

These disputes are based on a contractual relationship between two private parties. ${ }^{80}$ The most straightforward scenario is where two private parties have a contract containing a provision allocating or "sharing a tax burden between" them. ${ }^{81}$ Other kinds of clauses may include those where it is stipulated that a contracting party cannot make a profit or loss as a result of any changes to the tax law of a state; ${ }^{82}$ or provisions stating that one party will pass on to, or seek for the other, any tax benefits that it receives. ${ }^{83}$ A dispute may then arise if the underlying tax position changes, or if one party breaches the contract. $^{84}$ The only real limit on the kinds of disputes that may arise in this area is the creativity of those drafting the contracts. ${ }^{85}$

79 OECD Model Tax Convention on Income and Capital (OECD Publishing, 2010), art 25 (mutual agreement procedure). See also Cruz, above n 1, at 533; Michael J McIntyre "Comments on the OEDC Proposal for Secret and Mandatory Arbitration of International Tax Disputes" (2006) 7 Fla Tax Rev 622; Sed Crest "Why the OECD supports arbitration" International Tax Review (1 February 2007); and OECD Centre for Tax Policy and Administration Improving the Resolution of Tax Treaty Disputes (Committee on Fiscal Affairs, February 2007).

80 Luca CM Melchionna "Tax Disputes and International Commercial Arbitration" (2003) 74 Diritto e Pratica Tributaria Internazionale 769 at 774-786. See also Park "Arbitrability and Tax", above n 1, at [10-7].

81 Gaillard and Savage, above n 8, at 359; and Melchionna, above n 80, at 773. See, for an example, Sub-Contractor v Contractor (Award) ICC 5759, 1989 cited in Melchionna, above n 80, at 776.

82 See for example French Contractor v Libyan Employer in Sigvard Jarvin, Yves Derains and JeanJacques Arnaldez Collection of ICC arbitral awards 1986-1990 (Kluwer Law and Taxation Publishers, The Netherlands, 1994); and Melchionna, above n 80, at 774.

83 See, for an example, Sub-Contractor v Contractor (Award) ICC 5759, 1989 cited in Melchionna, above $\mathrm{n} 80$, at 776 .

84 See French Contractor v Libyan Employer, above n 82; and Melchionna, above n 80, at 775. For a hypothetical example of a kind of dispute that may arise see Thomas E Carbonneau and Andrew W Sheldrick "Tax Liability and Inarbitrability in International Commercial Arbitration" (1992) 1 J Transnatl L \& Poly 23 at 24.

85 For other examples, see generally Melchionna, above n 80. 


\section{Disputes Between Investors and States}

\section{Investment treaty arbitration}

In ITA investors can argue that changes in the taxation law of the host-state, which affect the investor, breach one of several treaty standards. For example, an investor may allege a breach of the fair and equitable treatment standard, if a tax is imposed on them in an arbitrary or discriminatory manner. ${ }^{86} \mathrm{An}$ investor may also allege that tax laws are being used as a means of expropriation. ${ }^{87}$ William Park points out that "taxes lend themselves to characterization as a form of indirect or 'creeping' confiscation, which might in principle give rise to claims under investment treaty provisions related to expropriation and discrimination". ${ }^{88}$ These enquiries also fundamentally differ from those that this article will focus on. Like state-state disputes, these disputes are founded in treaties, although the private investor can invoke the rights within. As such, they are vertical in nature, involving the application of standards of international law. ${ }^{89}$

\section{International commercial arbitration}

In contrast, this article will focus on taxation disputes between investors and states that are horizontal in nature, being borne out of contractual relations. In order to do this, a greater understanding of the types of contracts and contractual clauses that may exist is required. The basic scenario that will be examined is a long-term concession contract between a host-state and an investor. A concession contract is one that "involves an agreement by a state to grant a privilege to conduct an enterprise of some sort for a defined period". ${ }^{90}$ The state transfers to the concessionaire "certain rights of powers which normally would belong to ... the state"91 but "retains ultimate ownership of the right". ${ }^{92}$ These contracts therefore have a character that is partly public and partly

86 See for example Occidental Exploration and Production Company v Ecuador (Award) (2004) 12 ICSID Rep 59. But this standard is excluded with respect to taxation disputes in some treaties. See Walde and Kolo, above n 1, at 434. See also at 432 for more information on other kinds of treaty standard.

87 Walde and Kolo, above n 1, at 425.

88 Park "Arbitrability and Tax", above n 1, at [10-18]. See for example Encana v Republic of Ecuador (Award) (2006) 45 ILM 895.

89 However, they provide a useful comparator. See section $\mathrm{V}(\mathrm{C})(1)(\mathrm{c})(\mathrm{i})$ below at 43 . See also McLachlan, above n 50, at 294.

90 Kenneth S Carlston "International Role of Concession Agreements" (1957-58) 52 NWULRev 618 at 621.

91 Homayoun Mafi "Iran's Concession Agreements and the Role of the National Iranian Oil Company: Economic Development and Sovereign Immunity" (2008) 48 Nat Resources J 407 at 409.

92 Nicholas Miranda "Concession Agreements: From Private Contract to Public Policy" (2007) 117 Yale LJ 510 at 512. 
private. ${ }^{93}$ Long-term concession contracts usually concern major infrastructure projects or other significant projects, such as natural resource exploitation. ${ }^{94}$ The United Nations Conference on Trade and Development notes that "State contracts have played a major role in the foreign direct investment process". ${ }^{95}$

Three types of contractual clauses concerning tax are prevalent in concession contracts between states and investors. These are: provisions providing that the foreign party will abide by the taxation law of the host-state, provisions providing that the hoststate grants some limited tax exemption or reduction to the private party for a period of time, and provisions providing for stabilisation of the legal framework.

(a) Foreign party will abide by the tax law of the host-state

The Production Sharing Agreement at issue in Heritage Oil's dispute with Uganda provides perhaps the best example of a general provision that stipulates that a foreign investor will abide by the taxation law of the host-state. Art 14 provided that: ${ }^{96}$

All central, district, administrative, municipal and other local administrators or other taxes, duties, levies or other lawful impositions applicable to licensee shall be paid by the licensee in accordance with the laws of Uganda in a timely fashion.

A mineral exploration agreement between the Republic of Liberia and Magma Mineral Resources Inc provides another example. ${ }^{97}$ Art 13.1 provided that:

The Operator shall be liable to all taxes, fees, duties, excises, and other charges imposed by Liberian Laws of general application, except as may be otherwise provided by other laws and administrative regulations granting exemptions from customs duties and excise taxes.

An agreement between the Government of Sierra Leone and an Italian investor includes a similar provision. ${ }^{98}$ That provision demonstrates that there may be an overlap between

93 Carlston, above n 90, at 621; Mafi, above n 91, at 414-415. See also Sapphire International Petroleum Ltd v National Iranian Oil Co (1967) 35 ILR 136.

94 United Nations Conference on Trade and Development State Contracts (UNCTAD/ITE/IIT/2004/11, 2004) at 3 [UNCTAD]. See also Joachim G Frick Arbitration and Complex International Contracts (Kluwer Law International, The Hague, 2001) at 4-5; and Carlston, above n 90, 621-622.

95 UNCTAD, above n 94, at 1. See also Carlston, above n 90, at 643; and Frick, above n 94, at 4.

96 Heritage Oil v Uganda Revenue Authority [2011] UGCommG 97.

97 Mineral Exploration Agreement Between the Republic of Liberia and Magma Mineral Resources (26th October 2005), sourced from Liberia Extractive Industries Transparency Initiative (LEITI) $<$ http://www.leiti.org.lr/>. 
the types of clauses being described. This is because, in addition to providing for the payment of taxes in accordance with local law, it also stipulates that the foreign investor will not have to pay tax if it is exempted under the "Development Certificate". Indeed, perhaps the most plausible scenario is that any concession agreement will make use of a mix of the clauses regarding taxation being described.

(b) Limited tax exemption or reduction for foreign party

Many examples can be given of tax exemption or reduction clauses. For example, an agreement between the Republic of Liberia and China-Union (Hong Kong) Mining Co Ltd, provided a long list of tax exemptions in Art 14.3. These included being exempt from various taxes for the first 25 years, ${ }^{99}$ receiving a cap (by way of dollar amount) on another kind of tax payable for the first 10 years $^{100}$ and having income tax capped at $25 \%$ for the first 25 years. ${ }^{101}$ Art 25 of the Production Sharing Agreement between the Republic of Togo and Oceanic Resources Ltd provides another good example, exempting Oceanic Resources Ltd from import taxes, duties and fees in reasonably detailed circumstances. ${ }^{102}$

\section{(c) Stabilisation clauses}

Stabilisation clauses "are found primarily in State contracts of long duration". ${ }^{103}$ They serve to minimise the political risk associated with contracting with a state that "has the power to change the relevant legislation or rules applicable to the contract". ${ }^{104}$ The state

98 Concessions Agreement, in Joint Venture Form, Between the Government of Sierra Leone, Represented by its Minister of Agriculture and Natural Resources and Guiseppe Lamarca of Turin, Italy, Managing Director of SILETI, Signed in Freetown, January 20, 1975, art 5.1.1 in Peter Fischer (ed) A Collection of International Concessions and Related Instruments: Contemporary Series (Volume 1, Oceanea Publications, United States of America, 1981) at 1.

99 Mineral Development Agreement between the Government of the Republic of Liberia, China-Union (Hong Kong) Mining Co Ltd and China-Union Investment (Liberia) Bong Mines Co Ltd (19 January 2009) sourced from Liberia Extractive Industries Transparency Initiative (LEITI) $<$ http://www.leiti.org.1r/> at art 14.3(b), (d) and (e).

100 Art 14.3(g).

101 Art 14.3(a).

102 Production Sharing Agreement Between the Republic of Togo and Oceanic Resources Ltd, 4 August 1977 in Peter Fischer (ed) A Collection of International Concessions and Related Instruments: Contemporary Series (Volume 7, Oceanea Publications, United States of America, 1981) at 243.

103 Georges R Delaume Law and Practice of Transnational Contracts (Oceana Publications, Dobbs Ferry, NY, 1975) at 44.

104 Frick, above n 94, at 174; Waelde and Ndi, above n 77, at 219 and 221; Delaume, above n 103, at 15; Peter D Cameron International Energy Investment Law: The Pursuit of Stability (Oxford University Press, Oxford, 2010) at [2.19]; and Lorenzo Cotula "Reconciling regulatory stability and evolution of environmental standards in investment contracts: Towards a rethink of stabilization clauses" (2008) 1 JWEL \& B 158 at 158. It is beyond the scope of this article to consider the legal 
party agrees not to make changes to the law in a manner detrimental to the rights of the foreign investor. ${ }^{105}$ Georges Delaume puts forward the following as a "typical example": ${ }^{106}$

Except as otherwise expressly provided herein, this Agreement ... shall be construed and have effect in accordance with the Law of Ghana as it exists at the 22nd day of January, one thousand nine hundred and sixty two ...

However, the scope of a stabilisation clause is often limited. ${ }^{107}$ In particular, "the scope of the clause may be narrowed to specific matters, such as taxation". ${ }^{108}$ Tax clauses can therefore be "a specific form of stabilization clause, protecting one party against adverse changes in the law of taxation". ${ }^{109}$ In terms of the manner by which taxes are stabilised, this might take the form of a freezing provision, where tax laws are frozen in a manner similar to the clause above, or a consistency clause, where changes to the law only apply to the investment if they are "consistent with the investment contract". ${ }^{110}$

Taxes can also be stabilised by various other means. For example, states will agree to set tax rates for the contractual arrangement, and stabilise those for the length of the agreement. This is what occurred in the Production Sharing Agreement between the Republic of Togo and Oceanic Resources Ltd, ${ }^{111}$ and the Foreign Investment Contract between the State of Chile and Noranda Mines Ltd. ${ }^{112}$ Further "governments will often agree that there will be no taxes other than those specified in the agreement". ${ }^{113}$ In the

effect or validity of such clauses. This article will assume that such a clause is capable of binding the state and has a legal effect. However, it should be noted that there is much literature examining the real utility of stabilisation clauses.

105 Frick, above n 94, at 174.

106 Delaume, above n 103, at 45 citing Master Agreement of February 8, 1962 between the Government of Ghana and Volta Aluminium Company Limited (Valco), art 47. See also AFM Maniruzzaman "The pursuit of stability in international energy investment contracts: A critical appraisal of the emerging trends" (2008) 1 JWEL \& B 121 at 123.

107 Delaume, above n 103, at 46.

108 Delaume, above n 103, at 46-47.

109 Frick, above n 94, at 175.

110 Cotula, above n 104, at 160.

111 Production Sharing Agreement Between the Republic of Togo and Oceanic Resources Ltd, above n 102 , art 15 , which provided that the tax rate would be set at $50 \%$ and stabilised "throughout the life" of the agreement.

112 Foreign Investment Contract Between the State of Chile and Noranda Mines Limited, Signed at Santiago, Chile, 15 July 1977 in Peter Fischer (ed) A Collection of International Concessions and Related Instruments: Contemporary Series (Volume 7, Oceanea Publications, United States of America, 1981) at 220. In that agreement a detailed tax regime was set out, including a stable income tax rate of $49.5 \%$ for the 30 year duration of the agreement.

113 Waelde and George, above n 77, at 224. 
Republic of Liberia and Magma Mineral Resources Inc contract, the stabilisation clause went so far as to guarantee that anything not provided for by the agreement would be governed by the tax law of the host-state at the date the agreement came into effect. ${ }^{114}$ This agreement serves to reinforce the likelihood of overlap between the types of tax clauses concession agreements contain. This is because it included a promise to pay the applicable taxes, various exemptions and tax reductions, and a comprehensive stabilisation clause. ${ }^{115}$

Last, stabilisation clauses may take the form of an economic balancing provision, whereby the host-state promises that if there are any changes in the tax law applicable to the investor, these changes will be offset via other means. ${ }^{116}$ Such balancing provisions can take several different forms. One example, provided by AFM Maniruzzaman, is as follows: ${ }^{117}$

In case of modifications to the tax regime ... that have consequences on the economics of this Contract, a corresponding factor will be included in the production share percentages to absorb the increase or decrease in the tax burden.

\section{Taxation and Arbitrability}

\section{A The Exercise of Sovereign Authority}

The arbitrability of taxation disputes in the context of international commercial arbitration provides an interesting case study. This is because tax law is a direct exercise of the sovereign authority of a state. Conventionally, taxation has been viewed as indivisible from state sovereignty. ${ }^{118}$ It has not infrequently been argued that "the

114 Mineral Exploration Agreement Between the Republic of Liberia and Magma Mineral Resources above n 97, art 14.4.

115 For more examples of stabilisation provisions see Raymond Doak Bishop, James Crawford, William Michael Reisman Foreign Investment Disputes: Cases, Materials and Commentary (Kluwer Law International, The Hague, 2005) at 288-292. See also S K Chatterjee "The Stabilisation Clause Myth in Investment Agreements" (1988) 5 J Intl Arb 97.

116 Cotula, above n 104, at 161.

117 Maniruzzaman, above n 106, at 127-128. Maniruzzaman provides further examples of clauses of this kind.

118 Roland Paris "The Globalization of Taxation? Electronic Commerce and the Transformation of the State" (2003) 47 International Studies Quarterly 153 at 153, 155 and 157; Diane M Ring "What's at Stake in the Sovereignty Debate?: International Tax and the Nation State" (2008-2009) 49 Va J Intl L 155 at 156; and Allison Christians "Sovereignty, Taxation, and Social Contract" (Legal Studies Research Paper Series Paper No 1063, August 2008) at 7-8. 
relationship between taxation and the emergence of the modern state was one of 'mutual constitution': taxes made the state, and the state made taxes." ${ }^{119}$

To unpack this idea that taxation is indivisible from state sovereignty it is appropriate to examine conceptions of sovereignty found in public international law. In public international law the "competence of states in respect of their territory is usually described in terms of sovereignty and jurisdiction". ${ }^{120}$ Jurisdiction refers to the ability of a state to exercise control over people. ${ }^{121}$ It is a key ingredient of state sovereignty, ${ }^{122}$ sovereignty being the basis of the nation state. Further: ${ }^{123}$

If states ... are conceived of as sovereign, then in this respect at least they are equal, and their sovereignty is in a major aspect a relation to other states (and to organizations of states) defined by law.

These relations between states necessitate exceptions to the jurisdiction of states. It is in this respect that the doctrine of sovereign immunity arises. Sovereign immunity therefore refers to the idea that the actions of a foreign state lie outside the jurisdictional competence of other states. ${ }^{124}$ Whilst initially sovereign immunity was much broader, a doctrine of restrictive immunity has developed. This distinguishes between acts jure imperii (governmental acts) and acts jure gestionis (acts relating to the commercial activities of the state). ${ }^{125}$ Under this restrictive theory, immunity is only granted for acts jure imperii, as these acts are "unique to the state". ${ }^{126}$ This doctrine of restrictive immunity is now "solidified in practice" and widely accepted. ${ }^{127}$ The United Nations Convention on Jurisdictional Immunities of States and Their Property reflects this solidification. ${ }^{128}$

119 Paris, above n 118, at 157.

120 James Crawford Brownlie's Principles of Public International Law (8th ed, Oxford University Press, Oxford, 2012) at 204.

121 Malcolm N Shaw International Law (6th ed, Cambridge University Press, New York, 2008) at 645; and Crawford, above n 120, at 456.

122 Shaw, above n 121, at 645; and Crawford, above n 120, at 456.

123 Crawford, above n 120, at 447.

124 Shaw, above n 121, at 699-700; Hans W Baade "The Operation of Foreign Public Law" (1995) 30 Tex Intl L J 429 at 494; and Felix D Strebel "The Enforcement of Foreign Judgments and Foreign Public Law" (1999) 21 Loy LA Intl and Comp L J 55 at 440.

125 Shaw, above n 121, at 701; Crawford, above n 120, at 488; and Baade, above n 124, at 440.

126 Shaw, above n 121, at 709; Crawford, above n 120, at 488; and Baade, above n 124, at 44.

127 Matthew McMenamin "State Immunity Before the International Court of Justice: Jurisdictional Immunities of the State (Germany v Italy) (2013) 44 VUWLR 189 at 192.

128 United Nations Convention on Jurisdictional Immunities of States and Their Property (opened for signature 17 January 2005, not yet in force), art 10; McMenamin, above n 127, at 192-193; and Crawford, above n 120, at 490. 
The important notion or facet of sovereignty for present purposes is that of acts jure imperii. When establishing what constitutes an act jure imperii the focus is on the nature of the act. ${ }^{129}$ It is well-established that exercise of taxation power is of the appropriate nature to constitute an act jure imperii. A "general tax claim" has been referred to as the "classic example of a sovereign or public right". ${ }^{130}$ This is because such a claim falls within the "categories of strictly political or public acts" which private citizens cannot undertake; for example: "internal administrative acts, [and] legislative acts". ${ }^{131}$ These acts were included by Hazel Fox in her "positive list of acts of a State classified as ... acta jure imperii". ${ }^{132}$ While Fox did not specifically mention taxation, it is undoubtedly a "core governmental function" that would fall within this category. ${ }^{133}$ Indeed, there are clear links that exist between taxes and necessary state revenues, and between taxes and economic management. ${ }^{134}$ Due to these links "any significant diminution of the modern state's capabilities as a taxing entity could have important political, not merely economic consequences". ${ }^{135}$ It is therefore evident that the right to tax (or not to tax) remains "central to the idea of statehood" and sovereignty. ${ }^{136}$

The fundamental link between sovereignty and taxation culminates in the concept of tax sovereignty which centres on "the premise that decisions about taxation should be made exclusively within nations, independent of outside concern and interference". ${ }^{137}$ Essentially, tax sovereignty comprises a distinct facet of territorial sovereignty. ${ }^{138}$ While one dispute being resolved by arbitration may not impinge on tax sovereignty, "the totality of events could be troubling". ${ }^{139}$ Tax issues, under the sovereignty objection, therefore warrant protection from arbitrability. In particular, arbitrability might undermine the nation state or the system of nation states. This is analogous to the

129 Shaw, above $\mathrm{n} 121$, at 709-710.

130 Baade, above n 124, at 479. See also Hersch Lauterpacht "The Problems of Jurisdictional Immunities of Foreign States" (1951) 28 BYBIL 220 at 237.

131 Shaw, above n 121, at 709.

132 Hazel Fox The Law of State Immunity (2nd ed, Oxford University Press, Oxford, 2008) at 504.

133 Fox, above $\mathrm{n} 132$, at 523.

134 Ring, above $\mathrm{n} 118$, at 167-170.

135 Paris, above $\mathrm{n} 118$, at 157.

136 Christians, above n 118, at 12 and Paris, above n 118, at 155.

137 Christians, above n 118, at 2; and Charles E McLure Jr "Globalization, Tax Rules and National Sovereignty" (2001) 55 BFIT 328 at 328-329 (emphasis added).

138 See for example Sixth Report on Jurisdictional Immunities of States and their Property, by Mr Sompong Sucharitkul Special Rapporteur [1984] vol 2, pt 1 YILC 5 at [84]: "The rationale behind the authority to tax or to collect levies lies in the supremacy of the territorial sovereign".

139 Ring, above $\mathrm{n} 118$, at 182 . This sovereignty objection may be rephrased as a concern about the use of a private law mechanism to resolve a public law dispute, involving public rights that belong to society. See William W Park "Private Adjudicators and the Public Interest: The Expanding Scope of International Arbitration" (1986) 12 Brook J Intl L 629 at 637-638. 
justification for sovereign immunity, which, as a "direct inference from the equality and independence of states" seeks to avoid the sovereignty of a state being "impugned". ${ }^{140}$

Accordingly, the arbitrability of taxation disputes provides a starker illustration of the issues surrounding arbitrability than other areas, given taxation is so closely aligned with the exercise of government power. ${ }^{141}$ Further, the context of international commercial arbitration particularly highlights the issues due to the horizontal framework meaning disputes fall outside the realm of public international law, which is better equipped to deal with issues of sovereignty.

\section{B Other Concerns}

Two subsidiary arguments are made concerning the inappropriateness of arbitration for resolving taxation disputes. First, it has been argued that tax is a "speciality area" and therefore is not "susceptible to resolution by reference to commercial good sense" and should not be arbitrable. ${ }^{142}$ Second, concerns have been raised that deciding such disputes through arbitration will diminish the ability to create judicial precedent. ${ }^{143}$

\section{A Principled Approach \\ A Drawing the Line}

It is suggested that a distinction should be drawn between disputes that involve the direct exercise of sovereign authority when it comes to taxation, and those that involve the indirect recognition of its effect on private or commercial relationships. Those that involve a direct exercise of sovereign authority should not be arbitrable. Conversely, those that involve the indirect recognition of the effect of tax laws should be.

Another way to phrase this distinction is as a distinction between those disputes that concern the substantive tax law matters of a jurisdiction, and those which are based on specific contractual standards, despite implicating issues relating to taxation. Under this approach, disputes as to substantive tax law would be inarbitrable because they necessarily involve a direct exercise of sovereign authority. In contrast, the application of contractual standards, despite relating to tax, merely indirectly recognises the effect of tax laws, and therefore can be arbitrable. This appears to be the distinction drawn by

140 Crawford, above n 120, at 488.

141 Many statutory rules that have traditionally been considered non-arbitrable, such as bankruptcy, and patent law, are envisaged to apply between private parties. See Carbonneau and Janson, above n 4, at 196.

142 Carbonneau and Sheldrick, above n 84, at 33, 34 and 38.

143 Park, above n 139, at 637. 
Pascal Ancel, who wrote that substantive tax law issues are all "of too much importance for the State to be left for settlement by a private jurisdiction" and that: ${ }^{144}$

even where - pursuant to the legal obligations arising under the contract and the principle of good faith - arbitrators are entitled to hold liable for damages a State which violates its obligations, they would not have the power to directly rule on the principle or amount of tax unduly imposed by the State.

In undertaking this analysis it is useful to consider the proposed distinction in the context of the kinds of contractual provisions that arise. It is envisaged that this distinction will mean that a provision stating an investor will abide by the tax law of the host-state, on its own, would not lead to arbitrable tax disputes. This is because the disputes likely to arise around such provisions would require substantive determinations relating to the host-state's tax law. In contrast, a provision allowing for limited tax exemptions or reductions for the foreign party would be arbitrable, insofar as it requires a determination of compliance with the contractual standard, and not a determination of substantive tax law matters. This type of provision sits on the borderline. For example, a provision stating that tax payable on income is capped at a certain rate may raise substantive tax law issues, such as: what constitutes income? This determination involves a direct exercise of the state's sovereign authority over tax law. However, if the parties are agreed as to what constitutes income, compliance with this kind of provision could be arbitrable. This would involve merely the indirect effect of a tax law, in order to assess compliance with the contractual provision. Last, stabilisation provisions would be arbitrable following this distinction. This is because disputes that arise surrounding these provisions are likely to only involve questions of compliance with the contractual standard, i.e. whether the state has reneged on its promise of a stable framework. These disputes only indirectly recognise the effect of tax laws, although this is not to say that the determination is easy or that complex issues do not arise. ${ }^{145}$

When examining the application of the distinction to the clauses discussed, what becomes clear is that the proposed distinction essentially creates a spectrum of situations, moving from non-arbitrable disputes to arbitrable disputes. Some disputes will more obviously be arbitrable or non-arbitrable, whereas others will lie in the middle of the spectrum and require a closer examination to determine whether they should be arbitrable or whether substantive tax issues are required to be resolved before the tribunal can decide the dispute.

144 Pascal Ancel "Arbitrage et Ordre Public Fiscal" [2001] Revue de L'Arbitrage 269 at 227-278.

145 See for example the issues in terms of the application of the stabilisation provision that arose in Duke Energy International Peru Investments No 1 Ltd $v$ Republic of Peru (Award) ICSID ARB/03/28, 18 August 2008. 


\section{B Justifications}

\section{$1 \quad$ Sovereignty}

(a) Jure imperii vs jure gestionis

Having established that a general tax claim falls within the purview of acts jure imperii, this section will examine how far this characterisation can take us in determining the appropriate limits on the use of sovereignty as a justification for the inarbitrability of tax disputes. It will argue that the distinction used in public international law between acts jure imperii and acts jure gestionis can, by analogy, provide useful support for the approach to the arbitrability of tax disputes proposed.

While recognising that tax matters may in general be viewed as matters jure imperii, it must also be recognised that states undertake an array of commercial activities that do not directly impede their sovereignty. ${ }^{146}$ This makes defining the parameters of sovereignty particularly important in order to ensure that the scope of arbitrability is not too wide or narrow. This trade-off has been described by Baade as follows: ${ }^{147}$

The customary international law rule of sovereign immunity illustrates the central importance of state sovereignty in the modern world. The restrictive theory of such immunity, on the other hand, demonstrates the need to accommodate respect for foreign sovereign rights to new circumstances, such as state trading.

Therefore, there is something useful to be gained from applying the analogy of the jure imperii/jure gestionis distinction to investor-state tax disputes. To begin, it is important to note that, as with any distinction, there is "no clear cut dividing line between acts done jure imperii and acts done jure gestionis". ${ }^{148}$ Rosalyn Higgins identifies this as a "key problem" in this area. ${ }^{149}$ In the light of this, one must consider what indicators are available as to whether an act is jure imperii or jure gestionis.

As previously mentioned, the focus is on the nature of the act, or by analogy, the dispute. ${ }^{150}$ According to James Crawford, this is to be construed as "precisely and

146 Crawford, above n 120, at 488.

147 Baade, above n 124, at 440.

148 The Owners of the Ship 'Philippine Admiral'v Wallem Shipping (Hong Kong) Ltd [1976] HKLR 512 (PC) at 540. See also Steven Loble "Disputes with States" Law Gazette (Singapore, April 2011).

149 Rosalyn Higgins Problems and Process: International Law and How to Use It (Oxford University Press, Oxford, 1994) at 82.

150 Higgins, above n 149, at 83. See also Littrell v United States of America [1995] 1 WLR 82 (CA) at 89. 
narrowly as is reasonably possible having regard to the factual and legal issues". ${ }^{151} \mathrm{He}$ notes that "[i]f so described, the transaction can fairly be classified as a 'commercial transaction' ... then the transaction will not lose that character or classification because extraneous facts or aspects surrounding the individual transaction suggest ... a different classification". Further, Higgins points out that there is a "tendency to turn towards the test of whether an act is one that may be performed by anyone, or only a sovereign". ${ }^{152}$ Ultimately, it is important to recognise that there is an element of making "value judgments which rest on political assumptions as to the proper sphere of state activities and of priorities in state policies" in applying the jure imperii/ jure gestionis distinction. ${ }^{153}$

The English Court of Appeal judgment in Littrell $v$ United States of America provides further guidance. In that case, the question was whether Mr Littrell could bring proceedings against the United States Government in the United Kingdom, for personal injury he suffered due to medical treatment received at a United States military hospital in the United Kingdom. ${ }^{154}$ The Court indicated that an act will be jure gestionis in circumstances where: ${ }^{155}$

(a) it is necessary in the interests of justice to individuals having such transactions with states to allow them to bring such transactions before the courts; (b) to require a state to answer a claim based upon such transactions does not involve a challenge to or inquiry into any act of sovereignty or governmental act of that state. It is, in accepted phrases, neither a threat to the dignity of the state, nor any interference with its sovereign functions.

Further, in deciding whether the act was jure imperii or jure gestionis on the facts of the case, Hoffmann LJ stated that: ${ }^{156}$

The context in which the act took place was the maintenance by the United States of a unit of the United States Air Force in the United Kingdom. This looks about as imperial an activity as could be imagined. But it would be facile to regard this context as determinative of the question. Acts done within that context could range from arrangements concerning the flights of the bombers - plainly jure imperii - to ordering milk for the base from a local dairy or careless driving by off-duty airmen on the roads of Suffolk. Both of the latter would seem to me to be jure gestionis,

151 James Crawford "International Law and Foreign Sovereigns: Distinguishing Immune Transactions" [1984] British Yearbook of International Law 75 at 96.

152 Higgins, above n 149, at 83.

153 Crawford, above n 151, at 89.

154 Littrell, above n 150, at 82.

155 Loble, above n 148; and Littrell, above n 150, at 89.

156 At 94-95. 
fairly within an area of private law activity. I do not think that there is a single test or 'bright line' by which cases on either side can be distinguished. Rather, there are a number of factors which may characterise the act as nearer to or further from the central military activity.

His Honour's method demonstrates clearly Crawford's point that it is important to define the act as precisely as possible. ${ }^{157}$ This is because it shows that on a first look the act might appear to be on one side of the line, whereas when examined more closely it might fall on the other. That this is the correct approach was affirmed by the House of Lords in Holland $v$ Lampen-Wolfe. ${ }^{158}$ It is suggested that based on these tests the resolution of substantive tax law issues fall on the jure imperii side of the line, whereas the resolution of disputes that only indirectly concern taxation, and are essentially based on contractual standards, fall on the jure gestionis side of the line.

Accordingly, in the context of tax disputes a broad approach will not suffice in distinguishing between jure imperii and jure gestionis. Such an approach may lead in either direction, depending on how it is framed. First, state contracts as to foreign investment viewed broadly involve the state acting in its commercial capacity, as opposed to its sovereign capacity. The UN Convention on Jurisdictional Immunities of States and Their Property makes explicit that investment contracts constitute commercial transactions. ${ }^{159}$ But this approach only goes so far. For example, where a contract provides for the arbitration of tax disputes this may bring in issues of jure imperii. Looking solely at the fact that a dispute involves taxation indirectly or directly, and therefore appears to be an act jure imperii suffers from the same issue of being too broad an enquiry. Within the heading of tax disputes, there are a range of types of dispute which must be considered. This can be analogised to the situation in Littrell where within the operation of the United States military in the United Kingdom, a range of actions were taken, only some of which were jure imperii.

Drilling deeper requires an examination of the range of disputes. As already discussed, the kinds of tax dispute that may arise may be divided between those that involve substantive tax law issues, and those that involve the application of a contractual standard to the dispute. Only the former category can be analogised to acts jure imperii and therefore defended from arbitrability on the basis of sovereignty. The latter, are the

157 This is often referred to as the process of individuation: Fox, above n 132, at 515; and Roger O'Keefe and Christian J Tams (eds) The United Nations Convention on Jurisdictional Immunities of States and Their Property: A Commentary (Oxford University Press, Oxford, 2013) at 66-67.

158 Holland v Lampen-Wolfe [2000] 1 WLR 1573 (HL) at 1577.

159 At least with respect to article 17: United Nations Convention on Jurisdictional Immunities of States and Their Property (opened for signature on 17 January 2005, not yet in force), annex to the Convention with respect to article 17. See also O'Keefe, above n 157, at 277. 
sorts of transactions where there is no challenge or threat to state sovereignty if the disputes are arbitrable. ${ }^{160}$

Further, provisions that merely involve contractual standards are not limited to the state. In other words, while a state may enter into a contract containing a contractual stabilisation clause, so too may two private investors, whereby one agrees to indemnify the other against any change in the underlying circumstances. In contrast, only a state can exercise a taxing power. Thus the jure imperii/ jure gestionis analogy suggests that sovereignty as a reason for inarbitrability only supports the inarbitrability of those disputes that involve a substantive application of tax law.

(b) Waiver of sovereignty?

Following through the analogy, it remains to be considered what the position would be if a state 'waived its sovereignty' by signing up to an arbitration clause explicitly providing for the arbitration of substantive tax law disputes. This is where the analogy becomes less apt, as assessing this from a jurisdictional basis one would assume that the state would be able to waive its sovereignty over substantive tax law issues and allow the tribunal to decide. However it is not a satisfying intellectual answer to the question of arbitrability to say that a dispute becomes arbitrable when a party agrees to it. ${ }^{161}$ This conflates the issue of arbitrability with jurisdiction.

Nonetheless, this may be exactly the position in the context of investor-state contracts. The answer to this dilemma relates closely to the questions of governing law. ${ }^{162}$ If the law governing arbitrability is that of the state in question, even if its law states substantive tax law issues are inarbitrable, it is likely the state would be precluded from relying on this fact. This may suggest that in this circumstance, the state could waive its sovereignty, and a convergence would occur between the scope of the arbitration agreement and arbitrability.

If the law governing arbitrability is that of the seat or transnational public policy, then it is unlikely the host-state waiving its sovereignty with respect to substantive tax disputes would effect the question of arbitrability. This is due to the broader implications for state sovereignty generally and the interaction between states that can be gauged when assessing how the proposed distinction squares with the rule against foreign enforcement of revenue laws.

160 See Littrell, above $\mathrm{n} 150$, at 89 . It is also important that they be arbitrable to allow justice to investors.

161 See section II(B)(1) above at 8 .

162 See section II(B) above at 7 . 
On this view, however, there is also likely to be a convergence between the scope of the arbitration agreement and arbitrability. This is because, in practice, it seems unlikely that states would submit to an arbitration clause that explicitly agrees to arbitrate substantive tax disputes. Because of this it is likely construing the scope of a general arbitration provision will reach the same result dictated by concerns of arbitrability. In some senses, arbitrability in this context becomes bound up with issues of contractual interpretation. From a practical perspective, this convergence is understandable. It makes little sense for a tribunal to broadly construe an arbitration clause, only to have to then consider the limiting function of arbitrability separately. Indeed, it has been proposed more generally that the two facets of an arbitrator's hybrid authority - the contractual basis deriving from the parties (i.e. jurisdiction) and the authority "as permitted to exist or as assisted by state authority" (i.e. arbitrability) "are in the process of assimilating each other". ${ }^{163}$

(c) Rule against foreign enforcement of revenue laws

The last thing that remains to be considered is how the broader implications for state sovereignty alluded to would occur if substantive tax disputes were arbitrable. This will be done through a discussion of how the proposed distinction squares with the rule against foreign enforcement of revenue laws in private international law. It has long been established, almost universally, that "the courts of one country will not enforce the penal and revenue laws of another country". ${ }^{164}$ Indeed, in 1775 Lord Mansfield stated that "no country ever takes notice of the revenue laws of another". ${ }^{165}$ This is an application of the broader principle that "enforcement jurisdiction may not be exercised in the territory of any other State without the consent of that State". ${ }^{166}$

Various rationales have been given for the rule against the foreign enforcement of revenue laws. The primary reason concerns state sovereignty, highlighting that matters concerning tax law sit on the borderline between private international law and public

163 Bernard G Poznanski "The Nature and Extent of an Arbitrator's Powers in International Commercial Arbitration" (1987) $4 \mathrm{~J}$ Intl Arb 71 at 72.

164 Dicey, above n 22, at [5-020] and [5R-019]; CMV Clarkson and Jonathan Hill The Conflict of Laws (4th ed, Oxford University Press, New York, 2011) at 49; John O'Brien Conflict of Laws (2nd ed, Cavendish, London, 1999) at 152; and FA Mann "Conflict of Laws and Public Law" (1971) 132 Recueil de Cours 107 at 166. See generally Municipal Council of Sydney v Bull [1909] 1 KB 7.

165 Holman v Johnson (1775) 1 Cowp 341, 98 ER 1120 (KB) at 1121.

166 Malcolm D Evans (ed) International Law (3rd ed, Oxford University Press, Oxford, 2010) at 335. See also Robert Jennings and Arthur Watts (eds) Oppenheim's International Law (9th ed, Oxford University Press, Oxford, 2008) at 490. 
international law. ${ }^{167}$ This justification was best put in Government of India v Taylor. In that case, Lord Keith of Avonholm stated that: ${ }^{168}$

One explanation for the rule thus illustrated may be thought to be that enforcement of a claim for taxes is but an extension of the sovereign power which imposed the taxes, and that an assertion of sovereign authority by one State within the territory of another ... is (treaty or convention apart) contrary to all concepts of independent sovereignties.

In this regard, Lord Somervell of Harrow drew a distinction between contractual claims and administrative claims: ${ }^{169}$

Our courts will apply foreign law if it is the proper law of a contract, the subject of a suit. Tax gathering is not a matter of contract but of authority and administration as between the State and those within its jurisdiction.

Accordingly "the courts of one country will not sit in judgment on the acts of government of another done within its own territory". ${ }^{170}$ This links into a second justification given for the rule. That is, disputes of this nature are best reserved for the "political branches of government". ${ }^{171}$ In the words of Judge Learned Hand: ${ }^{172}$

To pass upon the provisions for the public order of another State is, or at any rate should be, beyond the powers of the court; it involves the relations between the States themselves, with which courts are incompetent to deal ...

Thus, by prohibiting a foreign state from seeking to rely directly on its own revenue law in the courts of another state, ${ }^{173}$ the revenue rule protects the courts in preventing them from "scrutinizing foreign tax laws", and protects the relationship of mutual respect

167 Baade, above n 124, at 60.

168 Government of India v Taylor [1955] AC 491 (HL) at 511. See also, Dicey, above n 22, at [5-020], [5-021] and [5-032]; and Mann, above n 164, at 168.

169 Government of India v Taylor, above n 168, at 514. See also Dicey, above n 22, at [5-029]; and Baade, above n 124, at 478: "A foreign sovereign seeking to collect a tax deficiency abroad is not (except perhaps, in political theory) attempting to enforce a contractual obligation."

170 Dicey, above n 22, at [5-046].

171 Symeon C Symeonides "Choice of Law in the American Courts in 2001: Fifteenth Annual Survey" (2002) 50 Am J Comp L 1 at 7.

172 Moore v Mitchell $30 \mathrm{~F} 2 \mathrm{~d} 600$ (2d Cir 1929) at 604. See also Government of India v Taylor, above $\mathrm{n}$ 168 , at 511 .

173 Dicey, above n 22, at [5-025]. Foreign judgments for taxes will not be enforced on the basis of this rule: Dicey, above n 22, at [14-R020] and [14-022]; and Clarkson and Hill, above n 164, at 174 See also Colt industries Inc v Sarlie (No 2) [1966] 1 WLR 1287 (CA). 
between states from the results that could occur if this kind of adjudication were allowed. ${ }^{174}$

Following on from this, an important distinction is drawn between the enforcement and recognition of foreign revenue laws. While the enforcement (direct or indirect) of foreign revenue laws is prohibited, the recognition of foreign revenue laws is not. ${ }^{175}$ The rule allows a foreign revenue law to be recognised where it is relevant to the issue at hand, and there is no issue of enforcement. ${ }^{176}$ For example "a contract invalid according to a ... revenue law of its applicable law ... may be held to be invalid or unenforceable". ${ }^{177}$

It is suggested that the distinction proposed for the arbitrability of tax disputes is entirely consistent with the distinction between recognition and effect. Enforcement being prohibited under the revenue rule is akin to the non-arbitrability of substantive tax law issues. The rationale behind both is the fact that the direct exercise of sovereign authority is implicated. Further, the recognition of the effect of revenue laws is akin to the arbitrability of contractual disputes once the underlying tax law issues are decided. This is because, under this approach, the effect of the tax law is recognised in order to make a determination as to the contractual dispute, but arbitrators are not required to make decisions on substantive tax law matters.

Aside from the analogies to be drawn, the proposed distinction makes sense from a practical perspective, considering the existence of the revenue rule. The inarbitrability of substantive tax law disputes mitigates any potential issues that could arise with respect to enforcement of an award. If this were not the position it seems that two options would arise. Either the arbitrability of substantive tax disputes would allow the New York Convention to be used to both avoid and undermine the foreign revenue rule, ${ }^{178}$ or courts

174 Symeonides, above n 171, at 6 and 7. See also Baade, above n 124, at 483: Another justification given for the rule is that the complexity of tax law makes "[t]he even-handed application of such a body of law by a foreign court of general jurisdiction" challenging.

175 Dicey, above n 22, at [5-023]-[5-025]; and O'Brien, above n 164, at 153.

176 Dicey, above n 22, at [5-031]; and O'Brien, above n 164, at 154.

177 Dicey, above n 22, at [5-024]. The Act of State doctrine posits a similar distinction between directly ruling on the validity of acts of a sovereign state, and indirectly recognising the effect of such acts where no question of validity arises. See Yukos Capital SarL v OJSC Rosneft Oil Company [2011] EWHC 1461 (Comm) at [122]-[131].

178 See Sergei Paushok, CJSC Golden East Company and CJSC Vostokneftegaz Company $v$ The Government of Mongolia (Award on Jurisdiction and Liability) Marc Lalonde, Horacia A Grigera Naon and Brigitte Stern 28 April 2011, at [695] where this possibility is discussed, and advanced as a reason for refusing to arbitrate the substantive tax counterclaims made by Mongolia. See also Computer Sciences Corp v Iran (Award) (1986) 10 Iran-US CT Rep 269 at 312-313 where the Tribunal refused what was in essence a request for a declaration of taxes owed on this basis. 
may develop the public policy exception to enforcement under the New York Convention to refuse enforcement of arbitral awards that essentially seek to enforce a foreign revenue law in another jurisdiction. ${ }^{179}$ Neither of these positions would be desirable. In the former scenario, the New York Convention could essentially be transformed into a revenue-collecting device. This is not something that could have been conceived of at the time the Convention was drafted, and could be said to transform its nature. ${ }^{180}$ The latter scenario is undesirable, as it would see tribunals rendering awards that were unenforceable. ${ }^{181}$ Thus, practically speaking, it is clear that it is important to find a solution consistent with the foreign revenue rule.

While it may be viewed as old-fashioned to rely on the foreign revenue rule due to the fact that "substantial inroads" have been made into it by treaties and other reciprocal arrangements, the rule still exists as a general principle, and is particularly relevant in those situations where no such inroads exist. ${ }^{182}$ Further, the rule is derogated from against the backdrop of public international law. The fact that states have, in the exercise of their sovereign authority, agreed with other states to modify the rule on a reciprocal basis does not provide any insight into the ability of an arbitral tribunal established by contract to decide tax disputes, or into the issues with enforcing such awards under the New York Convention.

At best the inroads made into the rule could be viewed as decreasing the scope of the problems regarding enforceability of such awards. However, these inroads do not remove the fundamental issues that exist. This is because the enforcement of arbitral awards is likely outside the scope of many such agreements, some of which just deal with foreign judgments, or administrative assistance, meaning the foreign revenue rule may still be a relevant consideration with respect to arbitral awards. ${ }^{183}$ Further, the

179 The United Nations New York Convention on the Recognition and Enforcement of Foreign Arbitral Awards 330 UNTS 3 (opened for signature 10 June 1958, entered into force 7 June 1959), art $\mathrm{V}(2)(\mathrm{b})$. This development would likely be done on the basis that it "can hardly be supposed that foreign arbitral awards will be more readily enforced or recognised ... than are foreign judgments": Dicey, above n 22, at [16-123].

180 United Nations Commission on International Trade Law "1958 - Convention on the Recognition and Enforcement of Foreign Arbitral Awards - the 'New York' Convention: Objectives" UNCITRAL < www.uncitral.org $>$.

181 Baade, above n 124, at 477.

182 Dicey, above n 22, at [5-022] and [5-029]. See generally Brenda Mallinak "The Revenue Rule: A Common Law Doctrine for the Twenty-First Century" (2006) 17 Duke J Comp \& Intl L 79 at 94 and Strebel, above n 124, at 78. See for example OECD Model Tax Convention on Income and Capital (OECD Publishing, 2010), art 27; Reciprocal Enforcement of Judgments Act 1934 (NZ), s 3(3A); Trans-Tasman Proceedings Act 2010 (NZ), s 68; and Protocol amending the US-Japan Income Tax Treaty 2003 (signed 24 January 2013, yet to be ratified) amongst others.

183 See the examples given in n 182, above. See also Directive 2010/24/EU concerning mutual assistance for the recovery of claims relating to taxes, duties and other measures 2010 OJ L 84/1, 
enforcement of arbitral awards regarding substantive tax issues could lead to similar issues against the backdrop of state-state agreements as it does against the backdrop of the foreign revenue rule. This is because enforcement of arbitral awards could be used to circumvent the limits or defined scope of those agreements, in the same way it might be used to circumvent the application of the foreign revenue rule, implicating similar issues for the system of sovereign states. As a result, the ability of states to derogate from the foreign revenue rule does not detract from the arguments made based on the rule as to how far a tribunal established in contract can and should go, unarmed by the lex specialis of a treaty. ${ }^{184}$

\section{The nature of tax law}

The concern that tax law is a complex or speciality area, and as such should not be subject to arbitration, can be usefully explored by a more in depth consideration of the nature of tax law. The nature of tax law suggests that it is indeed different from other areas of law. Indeed, tax law has been described as a "structure built on sand"; "illogical" and "incomprehensible". ${ }^{185}$ Compared to other areas of law, tax law is less able to match the legal rules to the factual situation or subject-matter that it governs. ${ }^{186}$ This is because of the issues associated with defining economic gains in order to allow

preamble (7). See further Joint Council of Europe/OECD Convention on Mutual Administrative Assistance in Tax Matters ETS 127 (opened for signature 25 January 1988, entered into force 1 April 1995); Protocol amending the Convention on Mutual Administrative Assistance in Tax Matters CETS 208 (opened for signature 27 May 2010, entered into force 1 June 2011).

184 Further, while this rule has been criticised on various bases that lie beyond the scope of this article, it does not appear to be going anywhere. Regarding criticisms, see generally O'Brien, above n 164, at 152; Anatol Dutta "Civil Claims of Foreign Sovereigns for Lost Taxes: The Big Tobacco Cases and the Revenue Rule" (2006) 7 EBOR 697; William J Kovatch Jr "Recognizing Foreign Tax Judgments: An Argument for the Revocation of the Revenue Rule" (2000) 22 Hous J Intl L 265; Lawrence Collins "Professor Lowenfeld and the Enforcement of Foreign Public Law" (2009) 42 International Law and Politics 125; Adrian Briggs "Crossing the River by Feeling the Stones: Rethinking the Law on Foreign Judgments" (2004) 8 SYBIL 1; and Strebel, above n 124. Regarding the prevalence of the rule, see for example the recent decision in Tullow Uganda Ltd v Heritage Oil and Gas Ltd, Heritage Oil plc [2013] EWHC 1656 (Comm) at [115]. See further Baade, above n 124, at 485; and Mann, above n 164, at 168.

185 See generally John Prebble "Income Taxation, A Structure Built on Sand" (2002) 24 Syd LR 301 [Structure Built on Sand]; John Prebble "Ectopia, Tax Law, and International Taxation" [1997] BTR 383 [Ectopia and International Taxation]; and John Prebble "Why is Tax Law Incomprehensible?" [1994] BTR 380 [Why is Tax Law Incomprehensible]. See also John Prebble "General Antiavoidance Rules as Regulatory Rules of the Fiscal System: suggestions for improvements to the New Zealand General Anti-Avoidance Rule" in Susy Frankel and Deborah Ryder (eds) Recalibrating Behaviour: Smarter Regulation in a Global World (Lexis Nexis, Wellington, 2013) [GAARs as Regulatory Rules].

186 Prebble "Structure Built on Sand", above n 185, at 305 and 308. 
them to be taxed. ${ }^{187}$ For example, economically speaking, profits or gains do not discriminate as to geography in the same way a state must if it seeks to operate a tax system. Economic gains do not exist in a particular space. However, for the purposes of tax law, gains need to be attributed to a particular jurisdiction. ${ }^{188}$ It is impossible to resolve this tension. ${ }^{189}$ As a result tax law can never be truly coherent. ${ }^{190}$

Due to these fundamental issues John Prebble reaches the following conclusions regarding the nature of tax law. First, he notes that "tax law tends to be ad hoc and incoherent, in the sense of lacking internal consistency" and that it "suffers from a lack of general principles that are usable". ${ }^{191}$ Second, he notes that "income tax law may be law as tax specialists know law, but it is not law as other people know it". ${ }^{192}$

These conclusions give credence to the assertion that tax disputes should be inarbitrable as tax is a speciality area. While arbitral tribunals frequently deal with complex areas of law, and courts have increasingly pronounced faith in the ability of arbitrators to do so, ${ }^{193}$ the lack of coherence in tax law, both in statutory rules and judicial decisions, suggests that the nature of tax law is beyond that of mere complexity: cases are contradictory, outcomes hard to predict, and issues of policy are clearly implicated in the arbitrary line drawing that can occur. ${ }^{194}$ This makes it inappropriate for an arbitral tribunal to make rulings on a nation's substantive tax law matters. As Carbonneau and Sheldrick note, outside the ordinary tax resolution processes of a country "there may be little room for predictable outcomes and accurate processes" which surely undermines the goals of arbitration: "[achieving] efficiency and expertise". ${ }^{195}$

\section{Transparency}

The last direct concern to address is the effect of the arbitrability of tax disputes on judicial precedent. It is suggested that deciding substantive tax law disputes outside of

187 Prebble "Structure Built on Sand", above n 185, at 305.

188 Prebble "Why Is Tax Law Incomprehensible", above n 185, at 385.

189 Prebble "Why Is Tax Law Incomprehensible", above n 185, at 391.

190 This concept was termed "ectopia" by John Prebble. This means "'displacement' or 'dislocation"'. It is particularly prevalent in tax law concerning business income. See Prebble "GAARs as Regulatory Rules", above n 185, at [10.5]; Prebble "Structure Built on Sand", above n 185, at 305-306.

191 Prebble "GAARs as Regulatory Rules", above n 185, at [10.5].

192 Prebble "Structure Built on Sand", above n 185, at 311.

193 See for example Mitsubishi Motors Corp v Soler Chrysler-Plymouth Inc 473 US 614 (1985) at 3355 and 3357-3358.

194 Ectopia is likely the cause of the similar factors described by Carbonneau and Sheldrick, above n 84, at 38-39.

195 Carbonneau and Sheldrick, above n 84, at 39-40. 
the court and tax system undermines the efficacy of the system. While the argument that the public resolution of disputes fertilises judicial precedent has been countered with the argument that "courts elaborate the law to deal with disputes; they do not entertain litigation in order to permit lawyers to elaborate the law", ${ }^{196}$ concerns regarding the effect on judicial precedent remain defensible. This is because the development of judicial precedent creates a transparent process, whereas commercial arbitrations are usually kept confidential. ${ }^{197}$ Transparency is particularly important where matters of taxation are involved. There are two reasons for this. The first is a rule of law point, and the second is a parity of treatment point.

An important facet of the rule of law is that the law must be accessible. ${ }^{198}$ This allows people to predict how the law may apply to their particular situation. ${ }^{199}$ It is especially important to have accessible decisions in the area of tax given the incoherent nature of tax law. In order for taxpayers to be able to predict how specific tax laws will be applied for them, it is often essential to have recourse to court decisions. ${ }^{200}$ Of course, due to the ad hoc nature of tax law, one may never be fully sure of the outcome, but the availability of judicial precedent certainly serves to mitigate some of the uncertainty that may arise in this area.

Further, the "consistency of arbitral decisions" is "closely connected with the issue of transparency". ${ }^{201}$ This encompasses the idea that "like cases [should] be treated alike"

196 Park, above n 139, at 637.

197 Karl-Heinz Bockstiegel "Commercial and Investment Arbitration: How Different are they Today? The Lalive Lecture 2012" (2012) 28 Arb Intl 577 at 586.

198 Harry Ebersohn "Tax Avoidance and the Rule at Law" (paper presented to Legal Research Foundation Tax Avoidance Symposium, Auckland, April 2011) at [10]; Harry Ebersohn "Tax Avoidance and the Rule of Law" [2012] NZLR 243 at 246; Vaughan Lowe "Res judicata and the Ryle of Law in International Arbitration" (1996) 8 Afr J Intl Comp L 38 at 48 and Thomas Bingham "The Rule of Law" (2007) 66 CLJ 67 at 69 -70.

199 Bockstiegel, above n 197, at 587.

200 It is important to briefly mention the role of tax advisory or guidance notes. The existence of these notes both confirms that the incoherency of tax law as an issue, and mitigates concerns with respect to taxpayers being able to determine how the law applies to them. However, crucially, such notes represent the non-binding view of the tax department as to the interpretation of the law, not necessarily the view of the courts. Judicial precedent therefore still has an important role to play. See for example US Inland Revenue Service "Tax Code, Regulations and Official Guidance" (4 September 2013) IRS <www.irs.gov>; US Inland Revenue Service "Understanding IRS Guidance A Brief Primer" (14 March 2013) IRS <www.irs.gov>/; Australian Taxation Office "Rulings and ATO View" (15 October 2007) Australian Government: Australian Taxation Office $<$ www.ato.gov.au>; and Australian Taxation Office "Precedential ATO Views" (29 October 2012) Australian Government: Australian Taxation Office <www.ato.gov.au>.

201 Bockstiegel, above n 197, at 587. 
and that "inconsistent decisions violate the parties' rights to justice". ${ }^{202}$ However, the parity of treatment point goes beyond the mere inconsistency of decisions, which is a problem courts also face with respect to the determination of substantive tax law matters. The key point here is that transparency is important in order to allow taxpayers, whether they are in similar circumstances, or different circumstances, to determine that they are receiving parity of treatment. There "is a public interest in seeing that the parties have been treated fairly" and in taxpayers knowing whether they are being treated in a consistent manner to others. ${ }^{203}$

It is for these reasons then, that concerns about the fertilisation of judicial precedent remain justified when it comes to the arbitrability of tax disputes. These concerns are particularly acute for the direct exercise of sovereign authority in the area of taxation, but are not so acute for disputes that merely recognise the effects of tax law. This is because disputes merely recognising the effects of tax law are unlikely to be affected by the complex nature of tax law. They are therefore likely to be more predictable, and subject to fewer concerns about parity of treatment.

\section{Further Support \\ $1 \quad$ Existing case law}

While there is no strict doctrine of precedent in international commercial arbitration it is useful to examine whether the case law (both judicial and arbitral) supports the proposed distinction. This article will first examine disputes founded in contract. Not only does the case law in this area support the arbitrability of contractual disputes indirectly involving taxation, but it also suggests that those disputes which implicate matters of sovereignty directly will not be arbitrable.

This article will then consider cases involving tax disputes from the Iran-US Claims Tribunal and ITA by way of comparison. An examination of these cases is best kept distinct, given they involve vertical relationships, being decided against the backdrop of public international law. ${ }^{204}$ While dealing primarily with jurisdictional issues in the light of this, these cases operate on a similar distinction to that being proposed, demonstrating that such a distinction is workable in practice. They also show similar policy

202 Lowe, above n 198, at 47-48.

203 Lowe, above n 198, at 48. Arguably this is particularly important for substantive tax issues, given these involve the exercise of sovereignty and relations between the state and its people. See generally Barbara Delcourt "Sovereignty" in Encyclopedia of Governance (SAGE Reference, Thousand Oaks, California, 2007) at 910-914; Gus van Harten "The Public-Private Distinction in the International Arbitration of Individual Claims Against the State" (2007) 56 ICLQ 371 at 376; and Ring, above $\mathrm{n} 118$, at 158,159 and 170.

204 McLachlan, above n 50, at 294. 
considerations to those discussed in this article in operation. Further, there is a good argument to be made that the jurisdictional inquiry in the Iran-US Claims Tribunal is analogous to arbitrability, thus providing even more support for the proposed distinction.

(a) Cases demonstrating contractual disputes are clearly arbitrable

Two cases demonstrate that contractual disputes implicating matters of taxation are arbitrable. These are AED Oil Limited v Puffin FPSO Limited, ${ }^{205}$ and Petrola Hellas $v$ The Greek State. ${ }^{206}$

AED Oil v Puffin is a decision of the Victorian Supreme Court, in Australia. The case concerned an agreement between two private parties. A dispute arose regarding the tax indemnification clause in the contract. In the course of the proceedings, it was submitted that the subject-matter of the dispute was not arbitrable, as it involved "statutory obligations" as well as "third party interests and public policy considerations". In considering this argument, Judd $\mathbf{J}$ made it clear that the dispute was capable of settlement by arbitration, because it was "in form and substance, a contractual dispute". This was in spite of the "existence of the underlying tax issue".

Petrola Hellas was an international commercial arbitration concerning an agreement between the Greek State and an investor. The agreement stipulated in art 10(4) that "any subsequent law imposing new taxes or customs duties was not applicable to Petrola, unless the new legislation created a more favourable taxation regime". ${ }^{207}$ This agreement was confirmed by legislative decree, and therefore became law. ${ }^{208}$ Subsequently, a once off extraordinary tax was imposed. The Tribunal considered whether Petrola was liable to pay the tax and concluded that the tax could not be applied as Petrola was "exempted by virtue of Art 10(4)". ${ }^{209}$ Second, the Tribunal stated that in the alternative, it would have found the Greek State "liable for damages on the ground that it had, in the exercise of its sovereign right, unilaterally cancelled its contractual obligations". ${ }^{210}$ Such damages would have been awarded "on the strength of the principles of good faith". ${ }^{211}$

205 AED Oil Limited v Puffin FPSO Limited [2009] VSC 534.

206 Petrola Hellas v The Greek State (Award) (1978) 11 Ybk Comm Arb 105.

207 At 106.

208 At 105 and 106.

209 At 107.

210 At 107.

211 At 107. 
This case represents a reasonably clear application of a contractual stabilisation provision. ${ }^{212}$ It is perhaps arguable that Petrola Hellas was founded on the fact that the contractual provision had been converted into law, but the alternative analysis provided by the Tribunal seems to suggest that a claim founded solely on contract also would have succeeded, albeit via a different route. The difference here is minimal in terms of final outcome.

(b) Cases demonstrating disputes implicating sovereignty are not arbitrable

The next group of cases add to those showing contractual provisions are clearly arbitrable by indicating that those implicating sovereignty directly are not. This additional layer gives rise to the proposed distinction, which is highlighted in some of these cases. There are four cases that warrant mentioning: Owner of a Lebanon Co $v$ African State, ${ }^{213}$ Duke v Peru, ${ }^{214}$ Engineering Co (Italy) v Engineering Co (Greece) ${ }^{215}$ and French Contractor $v$ Libyan Employer. ${ }^{216}$

Owner of a Lebanon Co was an international commercial arbitration, concerning contractual relations between the Lebanon Co and an African State. When disputes relating to taxation arose, the Tribunal stated, affirming the above, that it had "jurisdiction to decide all contractual matters falling within the scope of the arbitration clause, even when such matters are relevant to the tax court". ${ }^{217}$ It then went on to note that drawing a distinction between contractual matters and other matters: ${ }^{218}$

[allowed] the arbitral tribunal to respect both the arbitration clause conferring upon it the power to decide disputes relating to agreements between parties, and the exclusive jurisdiction of State courts in tax matters.

In saying this, as Melchionna points out, the Tribunal managed to avoid any issues surrounding tax sovereignty by "declaring the nature of the claims not as tax claims but as mere contractual ones". ${ }^{219}$ However, this case still clearly stands for the idea that only disputes involving contractual standards are capable of being resolved by arbitration,

212 See also Kaiser Bauxite Co v Jamaica (1999) 1 ICSID Rep 296, at 303. This decision also assumes that contractual disputes relating to stabilisation clauses will be arbitrable. Unfortunately nothing further can be drawn from this dispute as the matter was subsequently settled between the parties.

213 Owner of a Lebanon Co v African State (Award) (1992) 20 Yk Comm Arb 58.

214 Duke Energy International Peru Investments No 1 Ltd v Republic of Peru, above n 145.

215 Engineering Co (Italy) v Engineering Co (Greece) (1999) 24 Ybk Comm Arb 80.

216 French Contractor $v$ Libyan Employer, above $\mathrm{n} 82$.

217 At [2].

218 At [3].

219 Melchionna, above n 80, at 786. 
and it is appropriate for states to have exclusive jurisdiction in the resolution of substantive tax matters. ${ }^{220}$

Similar observations were made in the Engineering Co and French Contractor cases. These both involved disputes between private parties, regarding which party should bear the burden of taxes. In Engineering Co the dispute arose because the underlying tax position turned out to be different to that assumed when contracting, ${ }^{221}$ and in French Contractor the dispute arose when the tax position changed, and the French Contractor sought to rely on the contractual stipulation that it would "neither gain a profit nor suffer any loss as a result of changes" to the law. ${ }^{222}$ In each case the defendant contended that the dispute was concerned with substantive tax issues, and therefore inarbitrable. ${ }^{223}$

In French Contractor, while the issues relating to arbitrability were not fully fleshed out, ${ }^{224}$ the Tribunal noted that "[a]s far as Libyan taxation is concerned, it is entirely a matter for the [Libyan] authorities" and declined to give a decision. ${ }^{225}$ This is presumably because the determination of the dispute would have involved the Tribunal determining how much tax the employer owed under Libyan tax law. ${ }^{226}$

In contrast, Engineering Co provides an excellent example of a decision where the Tribunal has fully grappled with the theoretical issues. In rejecting the defendant's contention that the dispute was in essence concerned with the ability of the Greek Government to tax, the Tribunal first made it clear that "[c]onsiderations of sovereignty are not to be dismissed lightly". ${ }^{227}$ However, it noted that a tribunal also has a duty to the parties to resolve the dispute. ${ }^{228}$ Recognising the conflict between the sovereign rights of

220 The decision in Joint Venture v State $W$ (Award) (2011) 36 Ybk Comm Arb 135 potentially goes against this. State $\mathrm{W}$ alleged the Joint Venture owed taxes, relying on a provision that the Joint Venture would be subject to the laws of State $\mathrm{W}$ in this regard. While the Tribunal dismissed this claim based on a limitations point, and did not explicitly address arbitrability, there are indications in the decision that the Tribunal considered it would have been able to resolve the substantive tax law issues had the limitation period not applied. These can be found at [188] where the Tribunal noted the Joint Venture had convincingly shown State W's tax calculations were wrong, and [189] where it was noted that State $\mathrm{W}$ made assumptions as to its own tax laws, and did not provide evidence to the Tribunal. However, given the limited consideration by the Tribunal, it is hard to draw wider conclusions based on this decision.

221 At 80-81.

222 At 10.

223 French Contractor v Libyan Employer, above n 82, at 10; and Engineering Co, above n 215, at [5].

224 In the excerpts, at least.

225 At 11.

226 At 10-11.

227 At [7] and [9].

228 At [7]. 
states and the duties of a tribunal, the Tribunal stated that it would not undertake a balancing exercise between the sovereign and private interests at stake. Rather, landing in a similar position to that in French Contractor, it would "carefully refrain from infringing upon the prerogatives of [the state]". ${ }^{229}$

Applying this to the facts, the Tribunal in Engineering Co went on to highlight the distinction between assessing the "validity of Greek law or ... the validity of the acts of the Government of Greece" and matters of contractual interpretation (in this case as to what the parties intended regarding the allocation of taxes). ${ }^{230}$ Decisions as to the correctness of the passing of tax legislation or particular tax assessments fell outside the Tribunal's "ambit", ${ }^{231}$ whereas the Tribunal was ultimately able to decide the issues before it, which merely concerned contractual interpretation. ${ }^{232}$ In the Tribunal's view, deciding the issues of contractual interpretation "could [not] be deemed to be offensive to state sovereignty". 233 The Tribunal therefore felt it was able to resolve disputes relating to taxation "insofar as [the] question [was] solely one of interpretation of the contracts entered into by the said parties". ${ }^{234}$

While these decisions clearly indicate that it is inappropriate for arbitral tribunals to decide substantive tax matters, and that there is a distinction to be drawn, it is important to recognise that the reasoning in these cases may have been affected by the fact that the Tribunals derived jurisdiction from two private parties. In particular, in disputes between private parties there appears to be no point arbitrating substantive tax disputes, as any award will not bind the relevant authorities. ${ }^{235}$ Further, in Engineering Co there are indications that perhaps if one of the parties was a state, a tribunal could decide substantive tax law disputes, but these are inconclusive. ${ }^{236}$

Last, in Duke v Peru, a case involving an investor-state contract providing for the stabilisation of existing tax laws, and ICSID arbitration, ${ }^{237}$ the Tribunal both made it

229 At [9].

230 At [12]-[15].

231 At $[10]$.

232 At [14]-[15].

233 At [15].

234 At [16].

235 AED Oil Limited $v$ Puffin FPSO Limited, above n 205, per Judd J.

236 See [34] where the Tribunal reject the submission that the Government of Greece should be added as a party to the proceedings, on the basis that "[t]he arbitral tribunal is not going to pass judgment on the validity of Greek law, or ... over the validity of the actions of the Government of Greece". In saying this, the Tribunal also noted (at [11]) that it "perfectly [understood] that the Government of Greece would find it patently offensive to its sovereign rights if a private body, like the arbitral tribunal, should somehow pass judgment" on the exercise of those rights.

237 At [2],[72] and [186]. 
clear that it could not deal with tax disputes directly implicating sovereignty, and drew a distinction with disputes of a contractual nature. The case involved a claim by Duke that Peru had breached a tax stabilisation provision. ${ }^{238}$ In deciding this point the Tribunal began by affirming that it did not have the "power to review the correctness" of decisions "as a matter of Peruvian tax law". ${ }^{239}$ It went on to say: ${ }^{240}$

[216] The Tribunal's jurisdiction, under this particular guarantee, is limited to determining whether the relevant decisions or interpretations of SUNAT and/or the Tax Court, be they right or wrong, are consistent with the tax regime stabilized for Claimant in the DEI Bermuda [contract]. The Tribunal's standard is therefore comparative in nature, rather than absolute.

The distinction being drawn here was captured succinctly in the Decision on Jurisdiction where the Tribunal stated that "[t]he issue before the Tribunal [was] not a dispute about taxes but, rather, an investment dispute arising out of the imposition of taxes". ${ }^{241}$

However, the broader applicability of these remarks may be limited. The Tribunal appears to have been more concerned with what the contract gave it jurisdiction to do, as opposed to arbitrability. In the light of this, it may not be possible to conclude that the Tribunal viewed "dispute[s] about taxes" as inarbitrable, despite the comments about the Tribunal's lack of power in that regard. In particular, the Tribunal stated that the reason it could not decide "matters concerning the interpretation of tax law" was "as a consequence of DEI Egenor's use of the tax amnesty system", suggesting that if Peruvian dispute resolution procedures had not been made use of then the Tribunal may have been able to look at substantive tax law matters. ${ }^{242}$ In saying this, the fact that these cases draw a consistent line regarding sovereignty should not be minimised or ignored.

(c) Comparison with cases that arise in a vertical context

(i) Investment treaty arbitration

Despite being derived from a vertical relationship, and applying international law standards, awards considering tax matters under investment treaties provide a useful

238 At [138].

239 At [215].

240 At [215]-[216].

241 Duke Energy International Peru Investments No 1 Ltd v Republic of Peru (Decision on Jurisdiction) ICSID ARB/03/28, 1 February 2006, at [159]. See also Amco v Republic of Indonesia (Resubmitted Case: Decision on Jurisdiction) (1988) 27 ILM 1281 at [126]-[127]. See also Gaillard, above n 65.

242 At [225]. It is important to mention that Duke v Peru was the subject of annulment proceedings, but that Peru's Application for Annulment was "dismissed in its entirety": Duke Energy International Peru Investments No 1, Limited v Republic of Peru (Annulment Proceeding) ICSID ARB/03/23, 1 March 2011 at [269]. 
comparator to the consideration of international commercial arbitration. This article will briefly consider three such awards: Occidental Exploration and Production Company $v$ Ecuador, ${ }^{243}$ Enron Corp and Ponderosa Assets $v$ The Argentine Republic ${ }^{244}$ and Paushok $v$ Mongolia. ${ }^{245}$

Occidental involved a dispute concerning refunds of value added tax. Arbitral proceedings were commenced under the Ecuador-US Bilateral Investment Treaty. The Tribunal found that it had jurisdiction under the Treaty, and proceeded to decide on liability. This involved considering whether Ecuador had accorded fair and equitable treatment to Occidental, and whether Ecuador had treated Occidental in a manner "no less favourable than that accorded in like situations to investments or activities of its own nationals and companies". ${ }^{246}$ Both of these standards were found to be breached by the tax treatment Ecuador gave Occidental. ${ }^{247}$

Paushok involved an allegation that Mongolia had breached its obligations under the Russia-Mongolia BIT by implementing a windfall profit tax on some commodities and a fee on foreign workers. ${ }^{248}$ After deciding that it had jurisdiction to consider these Treaty claims, the Tribunal applied the Fair and Equitable Treatment and Expropriation provisions. Essentially, the Tribunal considered whether the enactment and enforcement of the tax laws violated the applicable treaty standards. No breach was found. Thus, just as contractual standards are arbitrable in the horizontal context, a dispute based on the relevant treaty standards is arbitrable in the vertical context.

Further, in Paushok, Mongolia raised counterclaims requesting the Tribunal order payment of the disputed taxes. ${ }^{249}$ In determining whether it had jurisdiction over the counterclaims the Tribunal observed that the tax claims: $:^{250}$

[arose] out of Mongolian public law and exclusively [raised] issues of noncompliance with Mongolian public law, including the tax laws of Mongolia. All

243 Occidental, above n 86.

244 Enron Corp and Ponderosa Assets LP v The Argentine Republic (Decision on Jurisdiction) ICSID ARB/01/13, 14 January 2004.

245 Paushok, above n 178.

246 At 63.

247 At 63 .

248 At [11] and [109].

249 At [678]. There were many difficulties with these claims, including the fact that Paushok was not actually the taxpayer (at [685]), but for present purposes it is not necessary to go into depth in terms of the complicated inter-party relationships. For completeness, it is worth only noting that the taxpayer/collector relationship was not a linear one between Paushok and Mongolia.

250 At [694]. 
these issues squarely fall within the scope of the exclusive jurisdiction of Mongolian courts, [and] are matters governed by Mongolian public law ...

The Decision on Jurisdiction in Enron made similar remarks, noting that it would only judge "whether the rights of investors had been violated", not "whether such policies are right or wrong". ${ }^{251}$

Second, the Tribunal in Paushok noted that deciding the counterclaims would have had the: $:^{252}$

likely effect of advancing the enforcement of Mongolian tax laws by nonMongolian courts in respect of non-Mongolian nationals beyond limitations on the extraterritorial application of Mongolian tax laws rooted in public international law.

It is worth noting as a caveat, that the Tribunal did make special mention of the fact that its jurisdiction was founded on the Treaty, and not in contract. ${ }^{253}$

(ii) Iran-US Claims Tribunal jurisprudence

The Iran-United States Claim Tribunal was established under the Algiers Declarations "to resolve the crisis" in Iran-US relations stemming from the "November 1979 hostage crisis ... and the subsequent freezing of Iranian assets by the United States". 254 The Tribunal has jurisdiction to: ${ }^{255}$

decide claims of United States nationals against Iran and of Iranian nationals against the United States, which arise out of debts, contracts, expropriations or other measures affecting property rights ...

The decision in Computer Sciences Corp $v$ Iran is indicative of the Tribunal's approach to tax disputes. ${ }^{256}$ This case involved contracts for computer services between an American company and entities controlled by the Government of Iran. Computer Sciences sought reimbursement for taxes paid in excess of certain amounts. ${ }^{257}$ It also

251 At [29]-[30].

252 At [695].

253 At [685].

254 "About the Tribunal" Iran-United States Claim Tribunal <http://www.iusct.net/>; and Rahmatullah Khan Iran-United States Claims Tribunal: controversies, cases, and contribution (Kluwer Academic Publishers, Boston, 1990) at ix.

255 Declaration of the Government and Democratic And Popular Republic of Algeria Concerning the Settlement of Claims by the Government of the United States of America and The Government of the Republic of Iran (Claims Settlement Declaration), 19 January 1981, art II(1).

256 Computer Sciences, above n 178.

257 At 275. 
sought a declaration releasing it "from liability for [specified] Iranian taxes". ${ }^{258}$ In deciding the claims concerning reimbursement for taxes paid, the Tribunal drew a clear distinction between contractual and non-contractual claims, with only the former being arbitrable. In particular, it was noted that where an obligation to pay tax arose "from the application of the tax laws of Iran" and not "out of the Contracts" the Tribunal did not have any jurisdiction over the matter. ${ }^{259}$

A similar distinction is evident in other Iran-US Claims Tribunal decisions. For example in Aeronutronic Overseas Services $v$ Iran the Tribunal allowed the claimant to rely on the contractual provision requiring "the Air Force to reimburse the Claimant in the event taxes are imposed and required to be paid by the Claimant". ${ }^{260}$ However, with respect to the claimant's request for a declaration releasing it from future liability, and the counterclaims Iran made for the payment of taxes, the Tribunal in Aeronutronic Overseas Services found it lacked jurisdiction as such requests were essentially requests "that the Tribunal apply the tax laws of Iran". ${ }^{261}$ This principle has been consistently reaffirmed in Iran-US Claims Tribunal jurisprudence. ${ }^{262}$

258 At 275-276.

259 At $287-288$.

260 Aeronutronic Overseas Services v The Government of the Islamic Republic of Iran, The Air Force of the Islamic Republic of Iran (Award) (1986) 11 Iran-USCTR 223 at [55] and [71]. See also Development and Resources Corporation $v$ The Government of the Islamic Republic of Iran and others (Award) Iran-US Claims Tribunal 485-60-3, 25 June 1990 at [295]-[296] where the reimbursement of surtaxes was provided for by an agreement between the parties; Cosmos Engineering Inc $v$ Ministry of Roads and Transportation (Award) (1986) 13 Iran-USCTR 179 at [28] where a claim for the reimbursement of income taxes was entertained as reimbursement provisions were incorporated into the contract, but dismissed for lack of proof; and Arthur Young and Company $v$ The Islamic Republic of Iran and others (Award) Iran-US Claims Tribunal 338-484-1, 30 November 1987 at [63] where the Tribunal examined a stabilisation provision in the contract between the parties as to changes in tax laws.

261 At [72].

262 See for example Westinghouse Electric Corporation $v$ The Islamic Republic of Iran Air Force (Final Award) (1997) 33 Iran-USCTR 60 at [434]; TCSB Inc v Iran (Award) (1984) 5 Iran-USCTR 160; Combustion Engineering Inc, Vetco Inc, Natco UK Ltd $v$ The Islamic Republic of Iran and others (Partial Award) (1991) 26 Iran-USCTR 60 at [88]; Collins Systems International Inc v The Navy of the Islamic Republic of Iran (Award) Iran-US Claims Tribunal 526-431-2, 20 January 1992 at [92]; Development and Resources Corporation, above n 260, at [299], [380]-[381]; Cosmos Engineering Inc, above n 260, at [11]; Aeronutronic Overseas Services, above n 260, at [79]-[80]; Arthur Young and Company, above $\mathrm{n}$ 260, at [60]; Howard Needles Tammen and Bergendoff $v$ The Government of the Islamic Republic of Iran and others (Award) (1986) 11 Iran-USCTR 302 at [61]; and TME International $v$ The Government of the Islamic Republic of Iran and others (Award) Iran-US Claims Tribunal 473-357-1, 12 March 1990 at [130]. 
As in ITA, concerns were also raised in Computer Sciences regarding the implications of the foreign revenue rule. With respect to the claimant's request for a tax clearance certificate, the Tribunal noted that this was: ${ }^{263}$

essentially a request to enforce the tax laws of a sovereign state, in that what it seeks is a binding declaration of the taxes owed by the Claimant [and that it] is a 'universally accepted rule that public law cannot be extraterritorially enforced'.

(iii) Analysis

Thus, it is clear that the Iran-US Claims Tribunal and ITA jurisprudence follow a similar distinction to that being proposed. In particular, claims that amount to a direct exercise of sovereign authority do not fall within the tribunals' jurisdiction, whereas those claims that do not directly implicate sovereign authority, but involve the application of a contract or treaty based standard do. In saying this, it is important to bear in mind that these cases were considering whether these disputes fell within the tribunals' jurisdiction - not arbitrability. One must then ask what relevance this line of decisions has to the question of arbitrability.

It is suggested, that at the very least, these decisions indicate that there is a distinction that can effectively be drawn in practice between substantive tax law issues, that derive from an application of the tax law of a country, and standards based disputes which merely indirectly recognise the effect of the tax law of a state, whether these standards are international law standards or contractual.

Further, it could be argued that the jurisdictional question, in the Iran-US Claims Tribunal at least, was closer to the question of arbitrability than other determinations of jurisdiction. Jurisdiction is usually a question of what the two parties to the arbitration agreement have agreed to arbitrate, whereas arbitrability is a question of whether, having agreed to arbitrate a subject-matter, the arbitration can go ahead. While in one sense arbitrability touches on the question of jurisdiction, these are distinct enquiries. However, with the Iran-US Claims Tribunal, the jurisdictional question was a determination of whether the dispute fit within the broad parameters set out in the Algiers Declarations. This is closer to arbitrability than an ordinary determination of jurisdiction, as in one sense the Tribunal was deciding more generally what was appropriately in the domain of the Tribunal and what was appropriately left to the domain of the national courts of Iran and the United States. For example, it seems perfectly feasible that the Tribunal could have decided that counterclaims relating to tax

263 At 312-313. See also Arthur Young and Company, above n 260, at [78] which affirmed Computer Sciences on this point. 
arose out of the contracts, if it had thought this was an appropriate subject-matter for arbitration, as the only reason there was taxable activity was by virtue of the contracts. This view was in fact raised in dissent in Tribunal decisions. For example in Howard Needles $v$ Iran the dissent noted its objection to the majority finding a lack of jurisdiction over tax counterclaims. The dissent considered these claims related to performance of the contract, and arose out of the legal relationship between the parties. $^{264}$

Even if this analogy between arbitrability and Iran-US Claims Tribunal determinations relating to jurisdiction does not hold, similar policy considerations arise in formulating the distinctions articulated in these decisions, to those discussed with respect to arbitrability. In particular, both lines of cases considered sovereignty and the prohibition on the enforcement of foreign revenue laws. Additionally, it is suggested that from a practical standpoint the potential symmetry between ITA, Iran-US Claims Tribunal jurisprudence and international commercial arbitration with respect to tax disputes, despite arising in slightly different contexts, can be used to bolster the conclusion that the proposed distinction is the appropriate one. Last, as outlined, it is likely there will be a convergence between the question of jurisdiction and arbitrability in this area, which may enhance the relevance of these decisions.

\section{Move towards greater arbitrability}

Having considered specific cases, it remains to look at arbitrability in other areas of law. ${ }^{265}$ Distilling trends in determining arbitrability from these areas reveals two points which support the proposition that tax disputes should be arbitrable, insofar as they do not directly implicate sovereignty. First, while each country has different rules regarding arbitrability, there is a general consensus that the scope of arbitrability in international commercial arbitration has been expanding. ${ }^{266}$ Second, it appears that arbitrability is increasingly not about subject-matter per se, but more about what the tribunal is expected to do with that subject-matter.

The fact that more and more disputes are becoming arbitrable can be observed by reference to competition law, securities law, insolvency, intellectual property, illegality and fraud, bribery and corruption, natural resources, employment law, trade sanctions,

264 Howard Needles, above n 262, dissenting opinion. See further, the dissent in TME International, above $\mathrm{n} 262$, at [56].

265 See generally Born, above n 5, at 831-832 and Gaillard and Savage, above n 8, at [572].

266 Blackaby, above n 2, at [2115]. See also Born, above n 5, at 775-776; Craig, Park, and Paulsson, above n 21, at [5.07]; and Julian DM Lew, Loukas A Mistelis and Stefan M Kroll Comparative International Commercial Arbitration (Kluwer Law International, The Hague, 2003) at [9-41]. 
and consumer law. ${ }^{267}$ At a general level this supports a greater role for the arbitrability of tax disputes. However, what is particularly important in terms of distilling trends in determining arbitrability is that even in subject-matter areas where arbitrability is expanding, some disputes are still reserved for resolution by state courts. These appear to be those that question functions that are exclusively reserved for the state.

For example, while competition law disputes are now arbitrable in the United States and European Union, amongst other countries, ${ }^{268}$ this does not give tribunals "unlimited powers". ${ }^{269}$ In many jurisdictions, tribunals cannot grant individual "authorisations" or "exemptions" for transactions that may implicate competition law. ${ }^{270}$ Disputes concerning natural resources present a similar distinction. While historically disputes relating to "concession agreements and natural resources" were inarbitrable on the basis they involved matters of sovereignty, ${ }^{271}$ such disputes are now arbitrable to the extent that they involve "the commercial decisions made by States in the exercise of that sovereignty" and do not implicate the sovereignty to exploit or not exploit natural resources itself. ${ }^{272}$ Lew, Mistelis and Kroll support this distinction on the basis that: $:^{273}$

On the one hand the tribunal does not have to determine the validity of the states exercise of sovereign power. On the other hand it gives the private party the required protection which it might not get in the courts of the host state.

Further examples arise in the areas of insolvency law, intellectual property and bribery and corruption. ${ }^{274}$ While arbitrability has expanded in the area of insolvency by allowing "standard monetary claims against an insolvent party", 275 "pure" bankruptcy issues, i.e. those "matters relating to the adjudication of the insolvency itself or the verification of creditors' claims ${ }^{1276}$, remain inarbitrable. ${ }^{277}$ Similarly, disputes questioning

267 See generally Born, above n 5, at 831-832 and Gaillard and Savage, above n 8, at [572].

268 For instance, Australia, New Zealand and Canada. See Born, above n 5, at 795. This departure has been motivated by the United States Supreme Court decision in Mitsubishi v Soler. See Lew, Mistelis and Kroll, above n 266, at [9-47]; and Born, above n 5, at 792-794. See also Mitsubishi, above $n 193$.

269 Poudret and Besson, above n 19, at [351].

270 Poudret and Besson, above n 19, at [351].

271 Born, above n 5, at 831.

272 Blackaby, above n 2, at [2.142]-[2.143]; and Company $Z$ and others (Republic of Xanadu) v State Organisation ABC (Republic of Utopia) (Award) (1983) VII Ybk Comm Arb 94 at 112-114.

273 Lew, Mistelis and Kroll, above n 266, at [9-91].

274 On bribery and corruption see generally Lew, Mistelis and Kroll, above n 266, at [9-78]-[9-80] and [9-86]; Born, above $\mathrm{n}$ 5, at 803-805.

275 Lew, Mistelis and Kroll, above n 266, at [9-56].

276 Blackaby, above n 2, at [2.128]; and Lew, Mistelis and Kroll, above n 266, at [9-55].

277 Blackaby, above n 2, at [2.128]; and Lew, Mistelis and Kroll, above n 266, at [9-55]; and Born, above $\mathrm{n} 5$, at 809 . 
the validity or existence of intellectual property rights will be inarbitrable, as these are "plainly a matter for the public authorities of the State concerned ... being monopoly rights that only the State can grant". ${ }^{278}$ In contrast, contractual disputes, between a licensor and licensee for example, are now arbitrable. ${ }^{279}$

In the light of this it appears that arbitrability is increasingly not about subjectmatter per se, but more about what the arbitral tribunal is expected to do with that subject-matter. All of the matters which remain inarbitrable involve positive actions of the state regarding the granting of rights or the imposition or enforcement of noncontractual obligations. A further common characteristic is that they all have the potential to impact either third parties, or society as a whole. This can be contrasted to the expansion of arbitrability in situations where the dispute is solely contractual.

\section{Conclusion}

Thus, the fact that a dispute involves the subject-matter of taxation is not a bar to arbitrability. Rather, arbitrability is concerned with what the arbitral tribunal have been asked to do regarding the subject-matter of taxation. In accordance with the move away from subject-matter arbitrability, and the general trend in favour of arbitrability, if what the tribunal is asked to do is determine a contractual dispute that does not involve a determination of the validity of a state's sovereign actions, this should be arbitrable. On the other hand, if the tribunal is asked to determine a substantive tax dispute, implicating the sovereign interests of the state involved, this should not be arbitrable. As a general proposition it is likely that the only remaining strong-hold of the non-arbitrability doctrine will be those matters that directly impinge on or involve the sovereignty of the state, or system of states. This accords clearly with the general distinction put forward in this article.

In addition, the examination of the arbitrability of tax disputes has highlighted the fact that the role of the doctrine of non-arbitrability is becoming more and more limited. As arbitrability expands, the potential for it to fully align with jurisdiction becomes greater. This is true either legally, or practically, depending on the circumstances. The fact that arbitrability and jurisdiction appear to be converging aligns with a broader policy approach of holding parties accountable for the decisions they make, that can be seen with respect to states in the shift from a broad doctrine of state immunity, to a narrow view that involves distinguishing between acts jure gestionis and acts jure imperii, and the decrease in the scope of the non-arbitrability doctrine more generally.

278 Blackaby, above n 2, at [2.118].

279 Blackaby, above n 2, at [2.118]. But see Poudret and Besson, above n 19, at [355] regarding the Swiss law on the arbitrability of intellectual property issues. 
Despite this general observation, it is still important to consider the question of arbitrability, due to the fact it fulfils a fundamentally different function to questions of jurisdiction, in that it is not concerned with the consent of the parties. The distinction proposed, between those disputes which directly implicate issues of sovereignty and those that are merely contractual in nature, provides a principled resolution to the issue of arbitrability of tax disputes. It successfully reconciles considerations of sovereignty with the rights of states to enter into commercial arrangements. Further, it is a distinction capable of being supported with reference to a wide range of factors, including the nature of tax law, considerations relating to transparency, and the case law. Of course, in practice drawing the line between the two possibilities could be rather complex. Contractual consequences can have significant policy implications. However, if we accept that states are capable of engaging in commercial activity, this is a line that we must attempt to draw.

Further, given the distinction drawn by this article is one that is generally applied and not often derogated from, it could be viewed as a rule of transnational public policy, whether specific to taxation or of a more general application based on state sovereignty. This enquiry into principles of transnational public policy is related to the question of whether it can be said that there is a general principle of law in this area. ${ }^{280}$ Indeed, based on the evidence presented in this article a general principle of law appears to exist. ${ }^{281}$ However, further study is required to make decisive claims in that regard. What can be concluded is that transnational public policy could be used to decide arbitrability, mitigating choice of law issues. This approach is less focused on the consent of parties, and on finding the jurisdiction with the most involvement in a dispute - issues which inhibit the use or choice of the lex arbitri and the law governing the arbitration agreement. The potential use of transnational public policy also says something more generally about the expansive way in which arbitrability is developing, and the way in which it might develop in the future.

280 Statute of the International Court of Justice (adopted 26 June 1945, entered into force 24 October 1945), art 38(1)(c).

281 See Bin Cheng "General Principles of Law as Applied by International Courts and Tribunals" (Cambridge University Press, Cambridge, 1953) at 1, where Cheng notes that general principles of law are "based on an examination of the decisions of international courts and tribunals" and that such decisions "constitute the most important means for the determination of rules and principles of international law". See also Christopher A Ford "Judicial Discretion in International Jurisprudence: Article 38(1)(c) and 'General Principles of Law"' (1994) 5 Duke J Comp \& Intl L 35 and HC Gutteridge "The Meaning and Scope of Article 38(1)(c) of the Statute of the International Court of Justice (1952) 38 Transactions of the Grotius Society 125. 
It remains then, to make some brief comments on how the proposed distinction would fit procedurally within arbitration proceedings. The main issue concerns whether an arbitral tribunal can, and should, stay its proceedings whilst waiting for the resolution of court decisions on the substantive tax issues. This issue is different to the traditional issues that necessitate a consideration of the arbitral tribunal staying its proceedings, in that it involves no question of whether the tribunal should "stay the exercise of its jurisdiction". ${ }^{282}$ Rather, this is a situation where the tribunal cannot decide the matter, due to the lack of arbitrability. Further, this is not a situation where the arbitral tribunal and court are being asked to decide the same issue. There are two separate issues: the court's determination of the substantive tax matters and the arbitral tribunal's determination of the contractual consequences.

The International Law Association in its Final Report on Lis Pendens and Arbitration concluded that "an arbitral tribunal should have a discretion to stay its own proceedings in appropriate circumstances". ${ }^{283}$ It is suggested that an "appropriate circumstance" would include a situation where a substantive tax law issue underlying a contractual claim needs to be resolved. Indeed, the report went on to conclude that "tribunals should have confidence to exercise case management powers and be empowered to stay their own proceedings, even when the situation [does] not fulfil the traditional criteria of lis pendens" (as is the case here). It was noted that the "ultimate objective should be to achieve a fair result as between the parties, and in some circumstances this may mean waiting for the outcome of other proceedings". ${ }^{284}$

Thus, where underlying substantive tax issues need to be decided before the tribunal can render an award, it is appropriate that proceedings are stayed until such time as this issue can be resolved. ${ }^{285}$ Of course, tribunals in exercising their case management powers will need to be vigilant with respect to practical issues. For example, there may be circumstances where the host-state delays the resolution of the substantive tax issues, in which it would be appropriate for the arbitral tribunal to determine the contractual issues regardless of on-going court proceedings. Further, given the expense and time involved in organising international commercial arbitrations, the need to stay

282 McLachlan, above n 50, at 289.

283 Filip De Ly and Audley Sheppard "International Law Association Final Report on Lis Pendens and Arbitration" (2009) 25 Arb Intl 3, at [5.7]. See also Southern Pacific Properties (Middle East) Limited v Arab Republic of Egypt (Decision on Jurisdiction) (1995) 3 ICSID Rep 131.

284 At [5.11]

285 In many cases the issue of a stay of proceedings will only arise if an appeal as to tax liability is underway, the original determination of tax liability being what triggered the dispute, i.e. a tax assessment viewed by the investor as contrary to a stabilisation provision. 
proceedings should be determined as early in the process as possible. ${ }^{286}$ This would assist in facilitating "the efficient and economical conduct of the proceedings". ${ }^{287}$

Ultimately, there appears to be nothing procedurally that would prevent arbitral tribunals from applying the proposed distinction. Thus, in undertaking its review of the arbitrability of tax disputes in international commercial arbitration, this article has discerned a principled distinction that is not only supportable in principle, but will be workable in practice for tribunals and courts alike. It is hoped that this resolution, and the broader observations on arbitrability that have resulted from the discussion in this article, will assist in both the determination of future disputes, and the future development of the doctrine of arbitrability.

286 Blackaby, above n 2, at [6-105]; and Edward M Morgan "Contract Theory and the Sources of Rights: An Approach to the Arbitrability Question" (1987) 60 S Cal L Rev 1059 at 1081.

287 Blackaby, above n 2, at [6-33]. 


\section{Bibliography}

A Arbitral Awards

1 International commercial arbitrations

Company $Z$ and others (Republic of Xanadu) v State Organisation ABC (Republic of Utopia) (Award) (1983) VII Ybk Comm Arb 94.

Construction Co (USA) v Construction Co (Turkey) (2000) 25 Ybk Comm Arb 341.

Denmark Buyer v Spain Seller (1997) 22 Ybk Comm Arb 149.

Engineering Co (Italy) v Engineering Co (Greece) (1999) 24 Ybk Comm Arb 80.

French Contractor $v$ Libyan Employer in Sigvard Jarvin, Yves Derains and JeanJacques Arnaldez Collection of ICC arbitral awards 1986-1990 (Kluwer Law and Taxation Publishers, The Netherlands, 1994).

Joint Venture v State W (Award) (2011) 36 Ybk Comm Arb 135.

Owner of a Lebanon Co v African State (Award) (1992) 20 Yk Comm Arb 58.

Petrola Hellas v The Greek State (Award) (1978) 11 Ybk Comm Arb 105.

Sub-contractor v Contractor (1993) 23 Ybk Comm Arb 34.

2 International investment arbitrations

Amco v Republic of Indonesia (Resubmitted Case: Decision on Jurisdiction) (1988) 27 ILM 1281.

Duke Energy International Peru Investments No 1 Ltd v Republic of Peru (Award) ICSID ARB/03/28, 18 August 2008.

Duke Energy International Peru Investments No 1 Ltd v Republic of Peru (Decision on Jurisdiction) ICSID ARB/03/28, 1 February 2006.

Duke Energy International Peru Investments No 1, Limited v Republic of Peru (Annulment Proceeding) ICSID ARB/03/23, 1 March 2011 
Encana v Republic of Ecuador (Award) (2006) 45 ILM 895.

Enron Corp and Ponderosa Assets LP v The Argentine Republic (Decision on Jurisdiction) ICSID ARB/01/13, 14 January 2004.

Kaiser Bauxite Co v Jamaica (1999) 1 ICSID Rep 296.

Occidental Exploration and Production Company v Ecuador (Award) (2004) 12 ICSID Rep 59.

Sergei Paushok, CJSC Golden East Company and CJSC Vostokneftegaz Company v The Government of Mongolia (Award on Jurisdiction and Liability) Marc Lalonde, Horacia A Grigera Naon and Brigitte Stern 28 April 2011.

Southern Pacific Properties (Middle East) Limited v Arab Republic of Egypt (Decision on Jurisdiction) (1995) 3 ICSID Rep 131.

\section{Iran US Claims Tribunal}

Aeronutronic Overseas Services $v$ The Government of the Islamic Republic of Iran, The Air Force of the Islamic Republic of Iran (Award) (1986) 11 Iran-USCTR 223.

Arthur Young and Company $v$ The Islamic Republic of Iran and others (Award) Iran-US Claims Tribunal 338-484-1, 30 November 1987.

Collins Systems International Inc $v$ The Navy of the Islamic Republic of Iran (Award) Iran-US Claims Tribunal 526-431-2, 20 January 1992.

Combustion Engineering Inc, Vetco Inc, Natco UK Ltd $v$ The Islamic Republic of Iran and others (Partial Award) (1991) 26 Iran-USCTR 60.

Computer Sciences Corp v Iran (Award) (1986) 10 Iran-US CT Rep 269.

Cosmos Engineering Inc v Ministry of Roads and Transportation (Award) (1986) 13 Iran-USCTR 179.

Development and Resources Corporation $v$ The Government of the Islamic Republic of Iran and others (Award) Iran-US Claims Tribunal 485-60-3, 25 June 1990. 
Howard Needles Tammen and Bergendoff $v$ The Government of the Islamic Republic of Iran and others (Award) (1986) 11 Iran-USCTR 302.

TCSB Inc v Iran (Award) (1984) 5 Iran-USCTR 160.

TME International $v$ The Government of the Islamic Republic of Iran and others (Award) Iran-US Claims Tribunal 473-357-1, 12 March 1990.

Westinghouse Electric Corporation $v$ The Islamic Republic of Iran Air Force (Final Award) (1997) 33 Iran-USCTR 60.

4 Other

Sapphire International Petroleum Ltd v National Iranian Oil Co (1967) 35 ILR 136.

B Court decisions

$1 \quad$ Australia

AED Oil Limited v Puffin FPSO Limited [2009] VSC 534.

2 England

Colt industries Inc v Sarlie (No 2) [1966] 1 WLR 1287 (CA).

Government of India v Taylor [1955] AC 491 (HL).

Holland v Lampen-Wolfe [2000] 1 WLR 1573 (HL).

Holman v Johnson (1775) 1 Cowp 341, 98 ER 1120 (KB).

James Miller v Whitworth Street Estates [1970] 1 Lloyd's Rep 269; [1970] AC 583 (HL).

Littrell v United States of America [1995] 1 WLR 82 (CA).

Municipal Council of Sydney v Bull [1909] 1 KB 7.

Sulamerica v Enesa Engenharia [2012] EWCA Civ 638. 
Tullow Uganda Ltd v Heritage Oil and Gas Ltd, Heritage Oil plc [2013] EWHC 1656 (Comm).

Yukos Capital SarL v OJSC Rosneft Oil Company [2011] EWHC 1461 (Comm).

\section{$3 \quad$ Hong Kong}

The Owners of the Ship 'Philippine Admiral'v Wallem Shipping (Hong Kong) Ltd [1976] HKLR 512 (PC).

$4 \quad$ Uganda

Heritage Oil v Uganda Revenue Authority [2011] UGCommG 97.

\section{$5 \quad$ United States}

Mitsubishi Motors Corp v Soler Chrysler-Plymouth Inc 473 US 614 (1985).

Moore v Mitchell 30 F 2d 600 (2d Cir 1929).

\section{International Instruments}

Declaration of the Government and Democratic And Popular Republic of Algeria Concerning the Settlement of Claims by the Government of the United States of America and The Government of the Republic of Iran (Claims Settlement Declaration), 19 January 1981.

Joint Council of Europe/OECD Convention on Mutual Administrative Assistance in Tax Matters ETS 127 (opened for signature 25 January 1988, entered into force 1 April 1995); Protocol amending the Convention on Mutual Administrative Assistance in Tax Matters CETS 208 (opened for signature 27 May 2010, entered into force 1 June 2011).

Protocol amending the US-Japan Income Tax Treaty 2003 (signed 24 January 2013, yet to be ratified).

Statute of the International Court of Justice (adopted 26 June 1945, entered into force 24 October 1945), art 38(1)(c).

United Nations Convention on Jurisdictional Immunities of States and Their Property (opened for signature 17 January 2005, not yet in force). 
The United Nations New York Convention on the Recognition and Enforcement of Foreign Arbitral Awards 330 UNTS 3 (opened for signature 10 June 1958, entered into force 7 June 1959).

\section{Contracts}

The Concession Agreement for Gola Forest East and Gola Forest West, Forest Reserves (Ratification) Act 1977 in Peter Fischer (ed) A Collection of International Concessions and Related Instruments: Contemporary Series (Volume 1, Oceanea Publications, United States of America, 1981).

Concessions Agreement, in Joint Venture Form, Between the Government of Sierra Leone, Represented by its Minister of Agriculture and Natural Resources and Guiseppe Lamarca of Turin, Italy, Managing Director of SILETI, Signed in Freetown, January 20, 1975 in Peter Fischer (ed) A Collection of International Concessions and Related Instruments: Contemporary Series (Volume 1, Oceanea Publications, United States of America, 1981).

Foreign Investment Contract Between the State of Chile and Noranda Mines Limited, Signed at Santiago, Chile, 15 July 1977 in Peter Fischer (ed) A Collection of International Concessions and Related Instruments: Contemporary Series (Volume 7, Oceanea Publications, United States of America, 1981).

Mineral Development Agreement between the Government of the Republic of Liberia, China-Union (Hong Kong) Mining Co Ltd and China-Union Investment (Liberia) Bong Mines Co Ltd (19 January 2009) sourced from Liberia Extractive Industries Transparency Initiative (LEITI) <http://www.leiti.org.lr/>.

Mineral Exploration Agreement Between the Republic of Liberia and Magma Mineral Resources (26th October 2005), sourced from Liberia Extractive Industries Transparency Initiative (LEITI) <http://www.leiti.org.lr/>.

Production Sharing Agreement Between the Republic of Togo and Oceanic Resources Ltd, 4 August 1977 in Peter Fischer (ed) A Collection of International Concessions and Related Instruments: Contemporary Series (Volume 7, Oceanea Publications, United States of America, 1981). 


\section{E Books}

Raymond Doak Bishop, James Crawford, William Michael Reisman Foreign Investment Disputes: Cases, Materials and Commentary (Kluwer Law International, The Hague, 2005).

Nigel Blackaby and others Redfern and Hunter on International Arbitration (Oxford University Press, Oxford, 2009).

Gary B Born International Commercial Arbitration (Kluwer Law International, Austin, 2009).

Peter D Cameron International Energy Investment Law: The Pursuit of Stability (Oxford University Press, Oxford, 2010).

Bin Cheng "General Principles of Law as Applied by International Courts and Tribunals" (Cambridge University Press, Cambridge, 1953).

Okezie Chukwumerije Choice of Law in International Commercial Arbitration (Quorum Books, London, 1994).

CMV Clarkson and Jonathan Hill The Conflict of Laws (4th ed, Oxford University Press, New York, 2011)

Lord Collins of Mapesbury (Ed) Dicey, Morris and Collins on the Conflict of Laws (15th ed, Sweet and Maxwell, London, 2012)

W Laurence Craig, William W Park, and Jan Paulsson International Chamber of Commerce Arbitration (3rd ed, Oceana Publications, Dobbs Ferry NY, 2000).

James Crawford Brownlie's Principles of Public International Law (8th ed, Oxford University Press, Oxford, 2012).

Georges R Delaume Law and Practice of Transnational Contracts (Oceana Publications, Dobbs Ferry, NY, 1975).

Malcolm D Evans (ed) International Law (3rd ed, Oxford University Press, Oxford, 2010). 
Hazel Fox The Law of State Immunity (2nd ed, Oxford University Press, Oxford, 2008) at 504.

Joachim G Frick Arbitration and Complex International Contracts (Kluwer Law International, The Hague, 2001).

Emmanuel Gaillard and John Savage (eds) Fouchard, Gaillard, Goldman on International Commercial Arbitration (Kluwer Law International, The Hague, 1999).

Rosalyn Higgins Problems and Process: International Law and How to Use It (Oxford University Press, Oxford, 1994).

Albert Jan van den Berg (ed) International Arbitration 2006: Back to Basics? (Kluwer Law International, The Netherlands, 2007).

Albert Jan van den Berg The New York Arbitration Convention of 1958: Towards a Uniform Judicial Interpretation (Kluwer Law and Taxation Publishers, Netherlands, 1981).

Robert Jennings and Arthur Watts (eds) Oppenheim's International Law (9th ed, Oxford University Press, Oxford, 2008).

Rahmatullah Khan Iran-United States Claims Tribunal: controversies, cases, and contribution (Kluwer Academic Publishers, Boston, 1990).

Julian DM Lew, Loukas A Mistelis and Stefan M Kroll Comparative International Commercial Arbitration (Kluwer Law International, The Hague, 2003).

Campbell McLachlan Lis Pendens in International Litigation (Martinus Nijhoff Publishers, Lieden/Boston, 2009) at 189-190.

John O'Brien Conflict of Laws (2nd ed, Cavendish, London, 1999).

Roger O'Keefe and Christian J Tams (eds) The United Nations Convention on Jurisdictional Immunities of States and Their Property: A Commentary (Oxford University Press, Oxford, 2013) at 277.

William Park Arbitration of International Business Disputes: Studies in Law and Practice (OUP, Oxford, 2006). 
Jean-Francois Poudret and Sebastien Besson Comparative Law of International Arbitration (2nd ed, Sweet \& Maxwell, London, 2007).

Malcolm N Shaw International Law (6th ed, Cambridge University Press, New York, 2008).

David AR Williams and others Williams \& Kawharu on arbitration (Lexis Nexis, Wellington, 2011).

F $\quad$ Chapters in books

Karl-Heinz Bockstiegel "Public Policy and Arbitrability" in Pieter Sanders (ed) Comparative Arbitration Practice and Public Policy in Arbitration (ICCA Congress Series No 3, Kluwer Law and Taxation Publishers, New York, 1986).

Stavros L Brekoulakis "Law Applicable to Arbitrability: Revisiting the Revisited Lex Fori" in L Mistelis and S Brekoulakis (eds) Arbitrability: International and Comparative Perspectives (Kluwer Law International, The Netherlands, 2009).

Barbara Delcourt "Sovereignty" in Encyclopedia of Governance (SAGE Reference, Thousand Oaks, California, 2007).

Pierre Lalive "Transnational (or Truly International) Public Policy and International Arbitration" in Pieter Sanders (ed) Comparative Arbitration Practice and Public Policy in Arbitration (ICCA Congress Series No 3, Kluwer Law and Taxation Publishers, New York, 1986).

Pierre Mayer "Effect of International Public Policy in International Arbitration?" in Loukas A Mistelis and Julian DM Lew (eds) Pervasive Problems in International Arbitration (Kluwer Law International, The Netherlands, 2006).

Loukas A Mistelis "Arbitrability - International and Comparative Perspectives. Is Arbitrability a National or an International Law Issue" in Loukas A Mistelis and Stavros L Brekoulakis (eds) Arbitrability: International and Comparative Perspectives (Kluwer Law International, The Netherlands, 2009).

William W Park "Arbitrability and Tax" in Loukas A Mistelis and Stavros L Brekoulakis (eds) Arbitrability: International and Comparative Perspectives (Kluwer Law International, The Netherlands, 2009). 
John Prebble "General Anti-avoidance Rules as Regulatory Rules of the Fiscal System: suggestions for improvements to the New Zealand General Anti-Avoidance Rule" in Susy Frankel and Deborah Ryder (eds) Recalibrating Behaviour: Smarter Regulation in a Global World (Lexis Nexis, Wellington, 2013).

Karim Yousef "The Death of Inarbitrability" in Loukas A Mistelis and Stavros L Brekoulakis (eds) Arbitrability: International and Comparative Perspectives (Kluwer Law International, The Netherlands, 2009).

\section{$G \quad$ Articles}

Pascal Ancel "Arbitrage et Ordre Public Fiscal" [2001] Revue de L'Arbitrage 269.

Hans W Baade "The Operation of Foreign Public Law" (1995) 30 Tex Intl L J 429.

Ilias Bantekas "The Foundations of Arbitrability in International Commercial Arbitration" (2008) 27 Australian Yearbook of International Law 193.

Thomas Bingham "The Rule of Law" (2007) 66 CLJ 67.

Karl-Heinz Bockstiegel "Commercial and Investment Arbitration: How Different are they Today? The Lalive Lecture 2012" (2012) 28 Arb Intl 577 at 586.

Karl-Heinz Bockstiegel "Public Policy as a Limit to Arbitration and Enforcement" (paper presented at the 11th IBA International Arbitration Day and United Nations New York Convention Day, New York, February 2008)

Adrian Briggs "Crossing the River by Feeling the Stones: Rethinking the Law on Foreign Judgments" (2004) 8 SYBIL 1.

Mark A Buchanan "Public Policy and International Commercial Arbitration" (1988) 26 Am Bus LJ 511 at 514.

Thomas E Carbonneau with Francois Janson "Cartesian Logic and Frontier Politics: French and American Concepts of Arbitrability" (1994) 2 Tul J Intl \& Comp L 193.

Thomas E Carbonneau and Andrew W Sheldrick "Tax Liability and Inarbitrability in International Commercial Arbitration" (1992) 1 J Transnatl L \& Poly 23. 
Kenneth S Carlston "International Role of Concession Agreements" (1957-58) 52 NWULRev 618.

S K Chatterjee "The Stabilisation Clause Myth in Investment Agreements" (1988) 5 J Intl Arb 97.

Allison Christians "Sovereignty, Taxation, and Social Contract" (Legal Studies Research Paper Series Paper No 1063, August 2008).

Lawrence Collins "Professor Lowenfeld and the Enforcement of Foreign Public Law" (2009) 42 International Law and Politics 125.

Lorenzo Cotula "Reconciling regulatory stability and evolution of environmental standards in investment contracts: Towards a rethink of stabilization clauses" (2008) 1 JWEL \& B 158.

James Crawford "International Law and Foreign Sovereigns: Distinguishing Immune Transactions" [1984] British Yearbook of International Law 75.

Sed Crest "Why the OECD supports arbitration" International Tax Review (1 February 2007).

Natalia Quinones Cruz "International Tax Arbitration and the Sovereignty Objection: The South American Perspective" (2008) 51 Tax Notes International 533.

Mihail Danov "The law governing arbitrability under the Arbitration Act 1996" [2008] LMCLQ 536.

Filip De Ly and Audley Sheppard "International Law Association Final Report on Lis Pendens and Arbitration" (2009) 25 Arb Intl 3.

Anatol Dutta "Civil Claims of Foreign Sovereigns for Lost Taxes: The Big Tobacco Cases and the Revenue Rule" (2006) 7 EBOR 697.

Harry Ebersohn "Tax Avoidance and the Rule at Law" (paper presented to Legal Research Foundation Tax Avoidance Symposium, Auckland, April 2011).

Harry Ebersohn "Tax Avoidance and the Rule of Law" [2012] NZLR 243. 
Christopher A Ford "Judicial Discretion in International Jurisprudence: Article 38(1)(c) and 'General Principles of Law'" (1994) 5 Duke J Comp \& Intl L 35.

L Yves Fortier "Arbitrability of Disputes" in Gerald Aksen and others (eds) Global Reflections on International Law, Commerce and Dispute Resolution (ICC Publishing, Paris, 2005).

Emmanuel Gaillard "Tax Disputes Between States and Foreign Investors" (1997) 217 NYLJ 25.

Javier Garcia de Enterria "The Role of Public Policy in International Commercial Arbitration" (1989-1990) 21 Law \& Poly Int Bus 389.

HC Gutteridge "The Meaning and Scope of Article 38(1)(c) of the Statute of the International Court of Justice (1952) 38 Transactions of the Grotius Society 125.

Bernard Hanotiau "What Law Governs the Issue of Arbitrability?" (1996) 12 Arb Intl 391.

Therese Jansson "Arbitrability regarding patent law - an international study" Juridisk Publikation 1/2011.

Fifi Junita "Public Policy Exception in International Commercial Arbitration Promoting Uniform Model Norms" (2012) 5 Contemp Asia Arb J 45.

Antoine Kirry "Arbitrability: Current Trends in Europe" (1996) 12 Arb Intl 373.

William J Kovatch Jr "Recognizing Foreign Tax Judgments: An Argument for the Revocation of the Revenue Rule" (2000) 22 Hous J Intl L 265.

Hersch Lauterpacht "The Problems of Jurisdictional Immunities of Foreign States" (1951) 28 BYBIL 220 at 237.

Steven Loble "Disputes with States" Law Gazette (Singapore, April 2011).

Vaughan Lowe "Res judicata and the Ryle of Law in International Arbitration" (1996) 8 Afr J Intl Comp L 38.

AFM Maniruzzaman "The pursuit of stability in international energy investment contracts: A critical appraisal of the emerging trends" (2008) 1 JWEL \& B 121. 
Homayoun Mafi "Iran's Concession Agreements and the Role of the National Iranian Oil Company: Economic Development and Sovereign Immunity" (2008) 48 Nat Resources J 407.

Brenda Mallinak "The Revenue Rule: A Common Law Doctrine for the Twenty-First Century" (2006) 17 Duke J Comp \& Intl L 79.

FA Mann "Conflict of Laws and Public Law" (1971) 132 Recueil de Cours 107 at 166.

Michael J McIntyre "Comments on the OEDC Proposal for Secret and Mandatory Arbitration of International Tax Disputes" (2006) 7 Fla Tax Rev 622.

Charles E McLure Jr "Globalization, Tax Rules and National Sovereignty" (2001) 55 BFIT 328.

Matthew McMenamin "State Immunity Before the International Court of Justice: Jurisdictional Immunities of the State (Germany v Italy) (2013) 44 VUWLR 189.

Luca CM Melchionna "Tax Disputes and International Commercial Arbitration" (2003) 74 Diritto e Pratica Tributaria Internazionale 769.

Carrie Menkel-Meadow "Why and How to Study 'Transnational' Law" (2011) 1 UC Irvine Law Rev 97.

Nicholas Miranda "Concession Agreements: From Private Contract to Public Policy" (2007) 117 Yale LJ 510.

Edward M Morgan "Contract Theory and the Sources of Rights: An Approach to the Arbitrability Question" (1987) 60 S Cal L Rev 1059.

Roland Paris "The Globalization of Taxation? Electronic Commerce and the Transformation of the State" (2003) 47 International Studies Quarterly 153.

William W Park "Private Adjudicators and the Public Interest: The Expanding Scope of International Arbitration" (1986) 12 Brook J Intl L 629.

Bernard G Poznanski "The Nature and Extent of an Arbitrator's Powers in International Commercial Arbitration" (1987) 4 J Intl Arb 71. 
John Prebble "Ectopia, Tax Law, and International Taxation" [1997] BTR 383.

John Prebble "Income Taxation, A Structure Built on Sand" (2002) 24 Syd LR 301.

John Prebble "Why is Tax Law Incomprehensible?" [1994] BTR 380.

Michael Pryles "Reflections on Transnational Public Policy" (2007) 24 J Intl Arb 1.

Diane M Ring "What's at Stake in the Sovereignty Debate?: International Tax and the Nation State" (2008-2009) 49 Va J Intl L 155.

Felix D Strebel "The Enforcement of Foreign Judgments and Foreign Public Law" (1999) 21 Loy LA Intl and Comp L J 55.

Symeon C Symeonides "Choice of Law in the American Courts in 2001: Fifteenth Annual Survey" (2002) 50 Am J Comp L 1.

Ruth Teitelbaum "A Look At The Public Interest In Investment Arbitration: Is It Unique? What Should We Do About It?" (2010) 5 Berk J Intl L 54 at 60.

Gus van Harten "The Public-Private Distinction in the International Arbitration of Individual Claims Against the State" (2007) 56 ICLQ 371.

Thomas W Waelde and George Ndi "Stabilizing International Investment Commitments: International Law Versus Contract Interpretation" (1996) 31 Tex Intl LJ 215.

Thomas Walde and Abba Kolo "Investor-State Disputes: The Interface Between TreatyBased International Investment Protection and Fiscal Sovereignty" (2007) 35 Intertax 424.

Janet Walker "Arbitrability: Are there Limits" (paper presented at the LCIA Symposium, Montreal, October 2004).

\section{H Websites}

"About the Tribunal" Iran-United States Claim Tribunal < http://www.iusct.net/>;

Elias Biryabarema and Andrew Callus "Update 2 - Uganda and Heritage Oil face off in tax dispute" (4 April 2013)<www.reuters.com>. 
Fox Business "Heritage Says Tax Arbitration with Uganda Hasn't Concluded" (4 April 2013) <www.foxbusiness.com>.

Emily Gosden "Questor share tip: Heritage Oil falls on Ugandan tax dispute but Nigeria Remains Key" (11 April 2013) <www.telegraph.co.uk>.

Heritage Oil "Uganda" Heritage Oil <www.heritageoilplc.com>.

United Nations Commission on International Trade Law "1958 - Convention on the Recognition and Enforcement of Foreign Arbitral Awards - the 'New York' Convention: Objectives" UNCITRAL <www.uncitral.org>.

\section{Other}

Ad Hoc Group of Experts on International Cooperation in Tax Matters "Arbitration in International Tax Matters" (29 August 2001) ST/SG/AC.8/2001/CRP.15.

Australian Taxation Office "Rulings and ATO View" (15 October 2007) Australian Government: Australian Taxation Office <www.ato.gov.au>.

Australian Taxation Office "Precedential ATO Views" (29 October 2012) Australian Government: Australian Taxation Office <www.ato.gov.au>.

Directive 2010/24/EU concerning mutual assistance for the recovery of claims relating to taxes, duties and other measures 2010 OJ L 84/1.

Heritage Oil Plc "Heritage Oil Update in Relation to Arbitration Proceedings Against Ugandan Government" (press release, 4 April 2013).

International Law Association Committee on International Commercial Arbitration "Interim Report on Public Policy as a bar to Enforcement of International Arbitral Awards (International Law Association London Conference, 2000).

International Law Association Committee on International Commercial Arbitration "Final Report on Public Policy as a Bar to Enforcement of International Arbitral Awards" (International Law Association New Delhi Conference, 2002).

OECD Centre for Tax Policy and Administration Improving the Resolution of Tax Treaty Disputes (Committee on Fiscal Affairs, February 2007). 
OECD Model Tax Convention on Income and Capital (OECD Publishing, 2010), art 25 (mutual agreement procedure).

Reciprocal Enforcement of Judgments Act 1934 (NZ)

Sixth Report on Jurisdictional Immunities of States and their Property, by Mr Sompong Sucharitkul Special Rapporteur [1984] vol 2, pt 1 YILC 5.

Trans-Tasman Proceedings Act 2010 (NZ)

United Nations Conference on Trade and Development State Contracts (UNCTAD/ITE/IIT/2004/11, 2004).

US Inland Revenue Service "Tax Code, Regulations and Official Guidance" (4 September 2013) IRS < www.irs.gov> .

US Inland Revenue Service "Understanding IRS Guidance - A Brief Primer" (14 March 2013) IRS <www.irs.gov>/ 